\title{
APPLICATION OF A NOVEL CLAY STABILIZER TO MITIGATE FORMATION DAMAGE DUE TO CLAY SWELLING
}

\author{
A Thesis \\ by \\ TIMOTHY ALDEN CLARKE \\ Submitted to the Office of Graduate and Professional Studies of \\ Texas A\&M University \\ in partial fulfillment of the requirements for the degree of \\ MASTER OF SCIENCE
}

Chair of Committee, Hisham A. Nasr-El-Din

Committee Members, Timothy Dellapenna

David Burnett

Head of Department, $\quad$ A. Daniel Hill

December 2014

Major Subject: Petroleum Engineering

Copyright 2014 Timothy Clarke 


\begin{abstract}
Clay swelling and fines migration can cause formation damage of hydrocarbon bearing zones and prevent economic realization of oil/gas wells. Identification and management of clay particles in the formation is a necessary component of production and drilling engineers' responsibilities.

This research focuses on the application of a cationic inorganic Al/Zr-based polymer clay stabilizer to prevent swelling of smectite particles in a sandstone matrix. Previous work has focused on mitigating fines migration; swelling mitigation is tested here. Berea sandstone cores were injected with a montmorillonite slurry to supplement the very low concentration of naturally occurring swelling clays. The modified Berea cores were subjected to a unique aluminum/zirconium-based clay stabilizer, via coreflood, to determine the effect of the stabilizer as a clay control mechanism. Pressure differential across the core and analysis of the coreflood effluent were used to measure the effectiveness of the treatment.
\end{abstract}

The $\mathrm{Al} / \mathrm{Zr}$ stabilizer performed well as a means to prevent clay swelling. When compared to an untreated core, permeability loss due to clay swelling and fines migration was negligible. Performance of the stabilizer at different concentrations suggests that an increase in stabilizer concentration does not correlate directly with permeability maintenance. 


\section{DEDICATION}

This work is dedicated to John Galt. 


\section{ACKNOWLEDGEMENTS}

I extend great appreciation to Dr. Hisham Nasr-El-Din for carrying himself as a beacon of professionalism and wisdom in a hectic academic environment. Thanks also to David Burnett for his continued support of my academic pursuits, and to Dr. Tim Dellapenna for inspiring a young man to engage in meaningful research.

And thank you, Dear Wife, for holding down the fort and raising our daughter during my absence. I live for you two, too. 


\section{TABLE OF CONTENTS}

Page

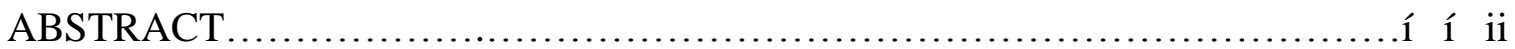

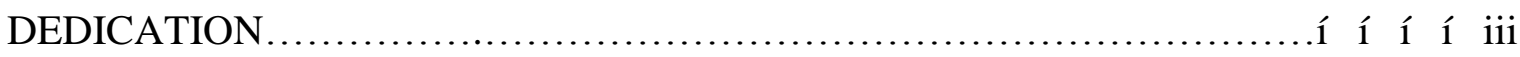

ACKNOWLEDGEMENTS.......................................

TABLE OF CONTENTS $\ldots \ldots \ldots \ldots \ldots \ldots \ldots \ldots \ldots \ldots \ldots \ldots \ldots \ldots \ldots \ldots \ldots \ldots \ldots \ldots$ « $\square \mathrm{v}$

LIST OF FIGURES..................................................... « « [vii

LIST OF TABLES........................................................... « [viii

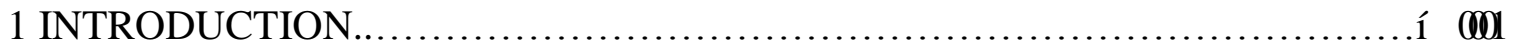

2 LITERATURE REVIEW ...................................................

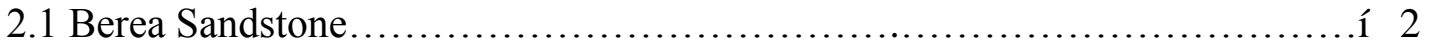

2.2 Native Berea Clays and Fines Migration.................................. 3

2.3 Swelling Clays......................................................... 4

2.4 Clay Stabilizers...................................................... 5

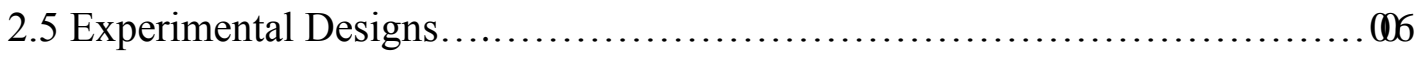

3 EXPERIMENTAL STUDIES ................................................... 7

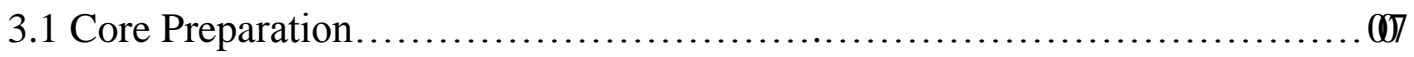

3.2 Slurry Injection Coreflood.......................................... 11

3.3 Stabilizer Treatment Coreflood...........................................

3.4 Analytical Tools...................................................... $\square 17$ 


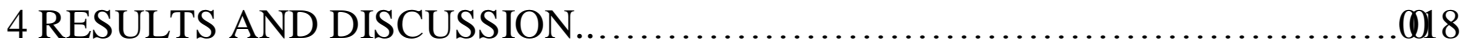

4.1 Slurry Injection: Determination, Pressure Profiles, and Testing............ $\square 18$

4.2 Stabilizer Treatment Pressure Profiles .............................« $\square 25$

4.3 Stabilizer Treatment ICP/OES Profiles............................« $\square 29$

4.4 CT Scan Comparisons........................................... $\square 35$

4.5 Experimental Error............................................... 37

4.6 Further Study................................................... $3 \square$

5. CONCLUSIONS AND SUMMARY .................................. 39

5.1 Conclusions................................................... 39

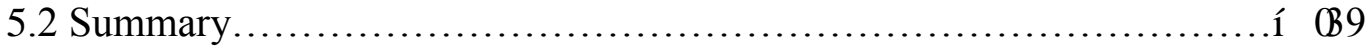

NOMENCLATURE..................................................... 40

REFERENCES.......................................................... 41 


\section{LIST OF FIGURES}

Page

Figure 1 Vacuum Saturator.......................................... 8

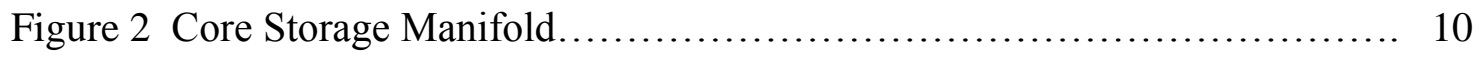

Figure 3 Coreflood Apparatus........................................ 12

Figure 4 Baseline ICP Analysis........................................ 13

Figure 5 Slurried Baseline........................................... 15

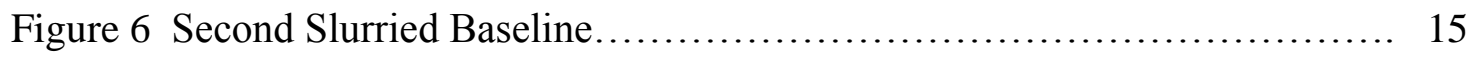

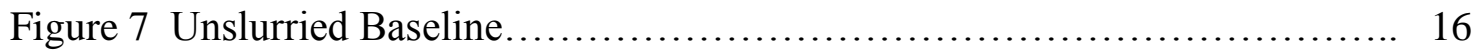

Figure 8 Poor Slurry Profiles........................................ 20

Figure 9 Adequate Slurry Profiles.................................... 21

Figure 10 Good Slurry Profiles...................................... 22

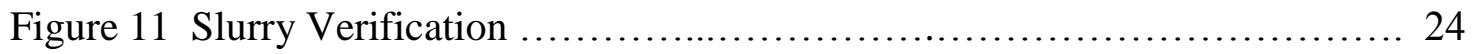

Figure $122 \mathrm{wt} \%$ Stabilizer A......................................... 26

Figure $134 \mathrm{wt} \%$ Stabilizer A......................................... 26

Figure 142 wt $\%$ Stabilizer A ICP ...................................... 30

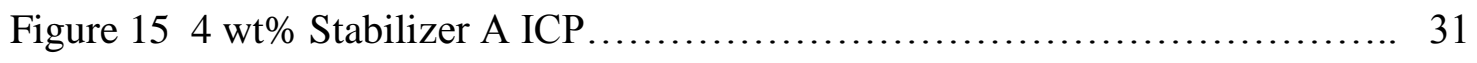

Figure 16 ICP/OES values presented by element............................ 32

Figure 17 CT Scan Number Comparison.................................. 36

Figure 18 CT Scan Porosity Comparison................................. 36 


\section{LIST OF TABLES}

Page

Table 1 Core Mass Tracker............................................ 9

Table 2 Generalized Core Characteristics................................... 10

Table 3 Permeability Comparison....................................... 28

Table 4 Coreflood Fluid Characterisitcs....................................... 28 


\section{INTRODUCTION}

Damage of oil bearing rock formations resulting from mismanagement of clays can occur at any point in the life of the well when fluid is injected into the formation. Chiefly, fines migration and clay swelling introduce significant potential for permeability loss. Much work has been committed to defining and minimizing each of these problems. This research focuses on the applicability of a cationic inorganic polymer, Stabilizer A, which proved successful in mitigation of fines migration, as a means to prevent swelling of smectite in a sandstone matrix.

Berea cores are subjected to experimentation in a coreflood apparatus wherein montmorillonite is injected into the sandstone matrix, permeability constancy is verified, and Stabilizer $\mathrm{A}$ is applied in a specific dose. In an attempt to damage the formation by swelling the montmorillonite, the core is then flooded with de-ionized water (DI). Pressure differential across the core is recorded and provides a metric for identifying permeability loss. Coreflood effluent samples are analyzed via Inductively Coupled Plasma/Optical Emission Spectrometry (ICP/OES), to measure the concentration of key cations during all portions of the coreflood. 


\section{LITERATURE REVIEW}

An understanding of factors influential to this experiment was necessary before the procedure could be designed. As such, this literature review follows a stepwise progression through the thought processes necessary to establish a responsible intellectual foundation. This includes reviewing characteristics of high permeability Berea, understanding the mechanics of clays therein, and establishing knowledge of contemporary clay stabilizers. The experimental methods of similar studies were reviewed for the purpose of expediting this experimental design.

\subsection{Berea Sandstone}

A detailed analysis by Churcher et al. (1991) identifies that Berea Sandstone consists of well rounded, well sorted quartz and feldspar grains cemented by dolomite and clays. The clay composition is dominated by kaolinite and includes illite and trace amounts of chlorite. These clays pose fines migration problems, but are not susceptible to swelling. Mohan et al. (1993) compare the effects of water-shock induced formation damage among different sandstones, and conclude that different types and concentrations of clays in the matrix result in varying degrees of damage. Specifically, crystalline swelling of smectite in Stevens sandstone was the significant cause of damage, by both restricting pore space and releasing fines to migrate. The mechanism of crystalline swelling will be identified in Section 2.3. Rock mineralogy of the Berea 
cores for this experiment was provided by the vendor, and resembles Berea cores used in other similar studies.

\subsection{Native Berea Clays and Fines Migration}

Berea sandstone consists of about $8 \%$ weight clays, the majority of which are kaolinite and illite (Khilar and Fogler 1984). Sharma et al. (1985) assert that these clays adhere to the pore walls by interaction of surface charges of quartz grains and irregularities of clay particles. They also found that the surface charge of the quartz was due to adsorption of ions from the brine, it changes with $\mathrm{pH}$, and it was more variable than that of the negatively charged clay. This implies the concept of a critical salt concentration, below which the surface charge of the pore walls changes from positive to negative and repels the predominately negative clay particles. Both Khilar and Fogler (1984) and Sharma et al. (1985) experimented with various brines to verify this concept. Khilar and Fogler (1984) identified $4250 \mathrm{ppm} \mathrm{NaCl}$ as the critical saturation for native Berea clays. Gray and Rex (1996) identify the migration as a combination of local shear from flowing brine and expansion of the double layer, and a change in surface charge negating weak van der Waal forces. High rate of expansion of the double layer causes sufficient shear to dislodge the clay, whereas low rate of expansion may not. However, osmotic mechanisms are not the primary cause of dislodgement; change of surface ionization, specifically with sodium chloride in Berea, drives fines migration. Musharova et al. (2012) identify increased sensitivity of clay dislodgment with increased temperature and increased $\mathrm{pH}$. 


\subsection{Swelling Clays}

Swelling clays are classified as part of the smectite clay mineral group, of which bentonite is an ore of mixed minerals and clay and montmorillonite is the dominant specie of clay (Trauger 1994). Smectites are utilized for a variety of commercial and industrial purposes, to include pond linings, pollutant absorption, soil nutrition, and medicine. In the oilfield, these clays are used as an additive for drilling mud, groundwater barriers in retention ponds, and wastewater treatment agents. When smectites occur in oil/gas reservoirs, they can cause significant formation damage if not managed correctly. Montmorillonite consists of two tetrahedral layers around an octahedral layer, forming a platelet $1 \mathrm{~nm}$ thick and up to 2 microns long, with a surface area of 600 to $800 \mathrm{~m}^{2} / \mathrm{g}$ (Trauger 1994). Oxides surround cations within each platelet, establishing a net negative charge and result in exchangeable cations occupying interplatelet layers. The exchangeability of ions between the layered platelets provides smectites a high affinity for water absorption; up to 5 times their weight and 15 times their bulk volume (Trauger 1994).

Detailed properties and parameters of smectites were investigated to prevent anomalous occurrences during this research: Leroy et al. (2005) and Liu (2010) conducted analyses of interlayer forces in bentonite, and how changes in ionic concentration in a fluid medium change the chemical and physical state thereof. Pusch and Karnland (1994) identify that smectites will convert to illite in an environment where temperatures are greater than $60^{\circ} \mathrm{C}$, pressure is greater than $30 \mathrm{MPa}$, and 
potassium is readily available. This information is useful during experimental design to establish boundaries for the experiment.

\subsection{Clay Stabilizers}

While promoting an innovative stabilizer, Weaver et al. (2011) wrote of the evolution of clay stabilizers over time and provided a detailed description of the mechanics of cationic stabilizers' interactions with clay platelets. Each platelet of montmorillonite consists of 3 layers: an octahedral layer of oxides and hydroxyls surrounding aluminum sandwiched by two tetrahedral layers of oxides around silicon. The outer surface of each platelet exhibits a net negative charge, allowing cationic stabilizers to situate between platelets. Because the stabilizer is poly-ionic, it binds to multiple sites on platelets and is highly resistant to ion exchange. This draws the platelets into a more stable structure and discourages absorption of water by the clay.

Peters and Stout (1976) and Reed (1971) explore the success of hydrolyzed zirconium and aluminum, respectively, as a method for stabilizing clay. The same mechanics apply for this treatment, but in high $\mathrm{pH}$ conditions the cations become saturated with hydroxide and lose their affinity for clay surfaces. Further problems with this treatment occur because neither $\mathrm{Al}(\mathrm{OH})_{3}$ nor $\mathrm{Zr}(\mathrm{OH})_{4}$ is soluble in water; tolerance of extreme $\mathrm{pH}$ conditions is necessary for an effective clay stabilizer.

Concerning application of stabilizers to shale formations, Maley et al. (2013) applied a variety of stabilizers to a variety of shales and concluded that no single stabilizer treatment demonstrated success for all shale variations. While microscopic 
clay/stabilizer interactions may be similar, macroscopic application must consider a greater array of variables.

\subsection{Experimental Designs}

El-Monier and Nasr-El-Din (2010 and 2011) published several papers detailing the success of a specific Aluminum/Zirconium-based cationic inorganic clay stabilizer in preventing fines migration in sandstone. This stabilizer, Stabilizer A, was treated to a battery of experimental conditions, to include variable temperature and $\mathrm{pH}$, and repeatedly demonstrated successful permeability maintenance in otherwise damaging conditions. Stabilizer A was determined to be much less toxic than other organic stabilizers, and less harmful to the environment. Their research provides a baseline for experimentation with Stabilizer A, much of which is reflected further in this paper.

To apply Stabilizer A to a smectite rich core while maintaining similar high permeability conditions as utilized by El-Monier and Nasr-El-Din, Berea cores required a pretreatment of montmorillonite slurry. DeVine et al. (2003) conducted experiments on reactions of hydrofluoric acid with drilling mud, which required forcing a montmorillonite based mud slurry into Berea cores. Their experimental method was a useful reference for determining an effective montmorillonite injection procedure.

Hou and Jones (2000) published a section in Encyclopedia of Analytical Chemistry which elucidated the inner workings of the Inductively Coupled Plasma (ICP) tool which provides analytical data for this experiment. 


\section{EXPERIMENTAL STUDIES}

\subsection{Core Preparation}

Previous experiments conducted with Stabilizer A (El-Monier and Nasr-El-Din 2011) used high permeability (>60 mD) Berea sandstone as the base matrix for treatment. The core vendor for this research delivered core material in large blocks, from which individual cores were drilled. A floor mounted, liquid lubricated drill press with a carbide tipped 1.5 inch inner diameter bit was used to cut cores in 19 inch lengths. These were divided into precise 6 inch lengths with a liquid lubricated tile saw. The lubricating liquid for both evolutions was a $\mathrm{KCl}$ solution of greater than $5 \mathrm{wt} \%$. 40 cores were drilled, cut, and immediately placed in an oven at $125^{\circ} \mathrm{F}$ for 24 hours.

After drying, cores were removed and allowed to cool to room temperature. The cores were assigned numeric identifiers and the dry mass of each core was recorded (Table 1). The cores were dry stored for several days while design of a vacuum saturation system was developed (Fig. 1). A 5 gallon bucket was used as a liquid saturation chamber, in which 38 of 40 cores were immersed in $5 \mathrm{wt} \% \mathrm{NaCl}$ brine. Brine concentration was selected to well exceed the critical salt concentration found by Khilar and Fogler (1984). Two cores were dry stored as reserve assets. The 5 gallon bucket was sealed with a modified lid, which allowed pressure communication between the bucket and environment through a NPT to barbed hose fitting, rigid poly hose, and a ball valve. A small pneumatic vacuum pump with a Venturi mechanism was connected to the bucket via the ball valve. Lab compressed air was applied to energize the pump and 
draw a vacuum on the bucket. Distortion in the sidewalls of the bucket indicated that negative pressure was achieved and maintained by isolating the environments with the ball valve, until released after 24 hours. After vacuum saturation in brine, the mass of each core was determined, that the pore volumes could be estimated (Table 1).

The cores were individually immersed in brine in a custom built storage manifold (Fig. 2) until further use. In the event of unique chemical treatments, isolating the cores seemed prudent to prevent cross contamination. Each cell in the manifold was checked weekly to ensure that all cores were fully submerged in brine. Core characteristics are measured and listed in Table 2.

\section{Core Vacuum Saturation}

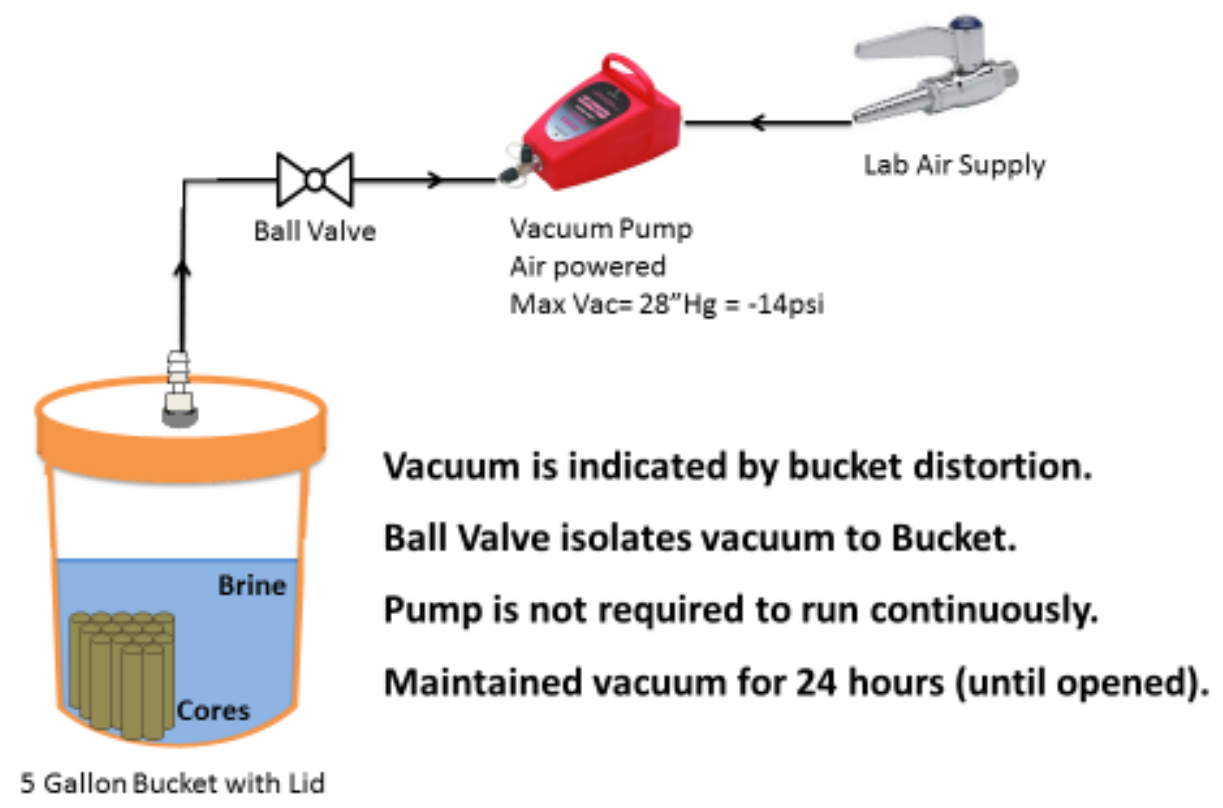

Fig. 1-Vacuum Saturator. Novel set-up to simultaneously saturate up to 401.5 inch by 6 inch cores. 
Table 1-Core Mass Tracker.

\begin{tabular}{|c|c|c|c|c|c|c|}
\hline \multicolumn{7}{|c|}{ Mass of Sandstone Cores: 1.5 Inch Diameter, 6 Inch Length } \\
\hline \multirow[b]{3}{*}{ Core ID\# } & \multicolumn{3}{|c|}{$\begin{array}{c}\text { Untreated } \\
\text { Raw Berea Sandstone }\end{array}$} & \multicolumn{3}{|c|}{$\begin{array}{c}\text { Treated with Slurry } \\
2.5 \mathrm{~g} / \mathrm{L} \text { Montmorillonite }\end{array}$} \\
\hline & Dry Mass (g) & Wet Mass (g) $\mathrm{F}$ & Pore Volume (cc) & Wet Mass (g) & Dry Mass (g) & Pore Volume (cc) \\
\hline & Oven 24 Hours & Jacuum 24 Hours & $\rho=1.05 \mathrm{~g} / \mathrm{cc}$ & After Flood & Oven 24 Hours & $\rho=1.05 \mathrm{~g} / \mathrm{cc}$ \\
\hline 1 & 361.69 & 380.46 & 18.77 & 393.45 & 360.13 & 33.32 \\
\hline 2 & 360.01 & 380.31 & 20.30 & 392.54 & 359.37 & 33.17 \\
\hline 3 & 359.78 & 383.15 & 23.37 & 394.26 & 358.85 & 35.41 \\
\hline 4 & 361.30 & 380.64 & 19.34 & 392.68 & 361.92 & 30.76 \\
\hline 5 & 361.19 & 379.88 & 18.69 & 389.93 & 359.52 & 30.41 \\
\hline 6 & 357.71 & 382.22 & 24.51 & 392.50 & 361.72 & 30.78 \\
\hline 7 & 360.83 & 378.33 & 17.50 & 389.06 & 358.73 & 30.33 \\
\hline 8 & 361.30 & 380.61 & 19.31 & 387.08 & 358.71 & 28.37 \\
\hline 9 & 360.35 & 380.19 & 19.84 & 388.00 & 357.16 & 30.84 \\
\hline 10 & 362.14 & 381.92 & 19.78 & 390.41 & 360.78 & 29.63 \\
\hline 11 & 359.56 & 380.57 & 21.01 & 387.97 & 359.33 & 28.64 \\
\hline 12 & 361.84 & 380.96 & 19.12 & 393.30 & 357.27 & 36.03 \\
\hline 13 & 356.89 & 382.26 & 25.37 & 390.78 & 361.52 & 29.26 \\
\hline 14 & 358.86 & 380.11 & 21.25 & 389.81 & 361.58 & 28.23 \\
\hline 15 & 362.66 & 379.32 & 16.66 & 391.80 & 361.25 & 30.55 \\
\hline 16 & 361.19 & 381.15 & 19.96 & 390.54 & 358.02 & 32.52 \\
\hline 17 & 357.85 & 382.05 & 24.20 & 392.02 & 360.41 & 31.61 \\
\hline 18 & 358.55 & 382.02 & 23.47 & 393.60 & 357.26 & 36.34 \\
\hline 19 & 358.44 & 382.84 & 24.40 & 393.15 & 360.79 & 32.36 \\
\hline 20 & 360.64 & 382.70 & 22.06 & 389.97 & 360.35 & 29.62 \\
\hline 21 & 356.40 & 380.88 & 24.48 & 392.99 & 360.21 & 32.78 \\
\hline 22 & 359.38 & 378.45 & 19.07 & 393.90 & 362.44 & 31.46 \\
\hline 23 & 359.84 & 382.10 & 22.26 & 393.45 & 361.92 & 31.53 \\
\hline 24 & 360.55 & 382.68 & 22.13 & 394.09 & 361.22 & 32.87 \\
\hline 25 & 358.30 & 381.63 & 23.33 & 391.47 & 361.24 & 30.23 \\
\hline 26 & 362.31 & 380.71 & 18.40 & 393.11 & 360.18 & 32.93 \\
\hline 27 & 361.49 & 380.29 & 18.80 & 388.71 & 357.76 & 30.95 \\
\hline 28 & 362.31 & 381.94 & 19.63 & 391.97 & 358.85 & 33.12 \\
\hline 29 & 358.91 & 378.54 & 19.63 & 392.65 & 360.46 & 32.19 \\
\hline 30 & 358.80 & 380.20 & 21.40 & 392.96 & 360.39 & 32.57 \\
\hline 31 & 361.93 & 378.52 & 16.59 & 391.91 & 358.86 & 33.05 \\
\hline 32 & 361.14 & 381.68 & 20.54 & 392.63 & 360.73 & 31.90 \\
\hline 33 & 358.62 & 380.92 & 22.30 & 388.06 & 356.55 & 31.51 \\
\hline 34 & 360.56 & 381.76 & 21.20 & 391.47 & 359.67 & 31.80 \\
\hline 35 & 358.08 & 379.11 & 21.03 & 390.37 & 358.11 & 32.26 \\
\hline 36 & 359.60 & 381.12 & 21.52 & 393.80 & 361.41 & 32.39 \\
\hline 37 & 360.71 & 377.77 & 17.06 & & Not Slurried & \\
\hline 38 & 361.50 & 379.84 & 18.34 & & Not Slurried & \\
\hline 39 & 360.61 & Not Sate & urated & & Not Slurried & \\
\hline 40 & 360.90 & Not Satu & urated & & Not Slurried & \\
\hline Average: & 360.12 & 380.79 & 20.67 & 391.57 & 359.85 & 31.71 \\
\hline St Dev: & 1.58 & 1.38 & 2.33 & 1.99 & 1.56 & 1.90 \\
\hline
\end{tabular}




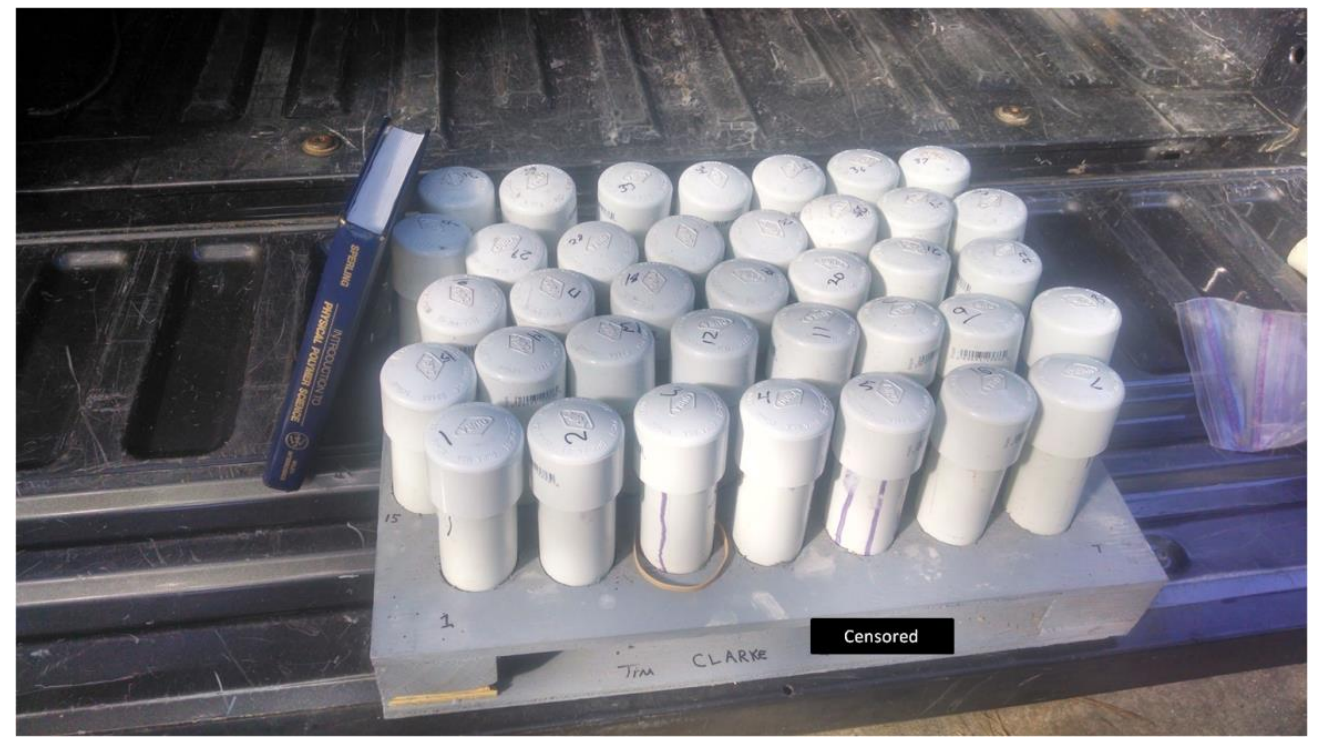

Fig. 2 - Core Storage Manifold. Constructed of plywood, pine, and PVC. Prevents cross contamination of uniquely treated cores.

Table 2-Generalized Core Characteristics.

$\begin{array}{rc}\text { Characteristic } & \text { Value } \\ \text { Crossectional Area }\left(\mathrm{cm}^{2}\right) & 11.40 \\ \text { Length (cm) } & 15.24 \\ \text { Bulk Volume (cc) } & 173.74 \\ \text { Pore Volume After Vacuum (cc) } & 19.68 \\ \text { Pore Volume After Flooding (cc) } & 30.20 \\ \text { Average Permeability (mD) } & 76.40 \\ \text { Porosity Range } & 0.11 \text { to } 0.17\end{array}$




\subsection{Slurry Injection Coreflood}

Based loosely on DeVine et al. (2003), several formulae for a montmorillonite slurry were developed. Necessary concentration of clay particles in the slurry was selected after consideration of several factors. First, the slurry was required to sit unagitated in the treatment accumulator of the coreflood apparatus (Fig. 3). If clay particle concentration was too high, settling would occur. Second, higher clay particle concentration could build a filter cake on the core before the clays had adequately permeated the pore volume. Third, the concentration of clay in the slurry determined the volume of slurry necessary for effective clay penetration of the pore space; a low volume, low concentration slurry injection would not introduce a viable quantity of clay. A slurry of $2.5 \mathrm{~g} / \mathrm{L}$ of montmorillonite mixed into $5 \mathrm{wt} \% \mathrm{NaCl}$ brine was selected to ensure that a significant quantity of clay remained suspended over the injection period without rapid creation of filter cake. 


\section{Coreflood Apparatus}

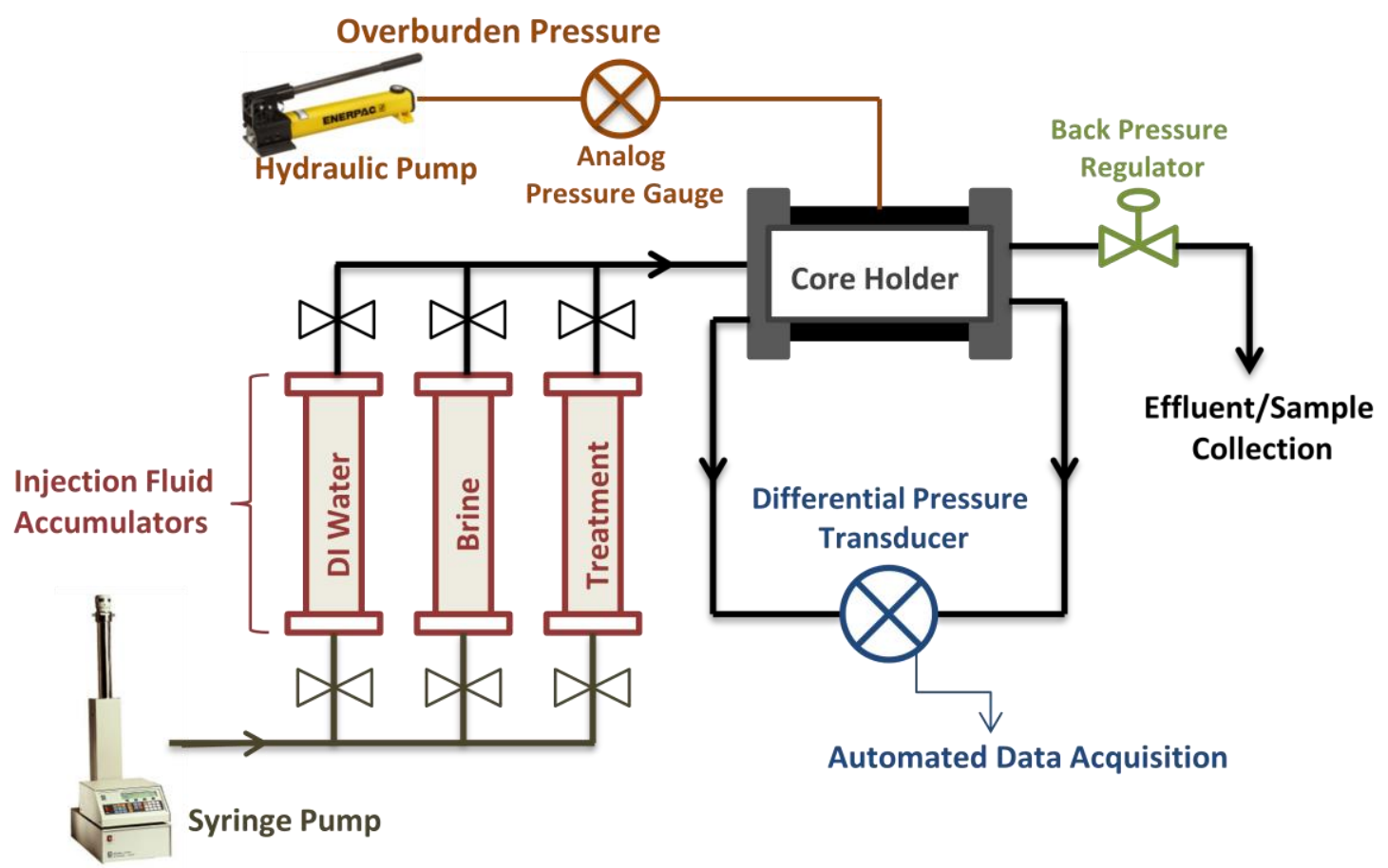

Fig. 3 - Coreflood Apparatus. Components are color coded: The red accumulators are oriented vertically, allowing suspended sediment to settle before being injected. Back pressure regulator is energized with high pressure nitrogen. Overburden pressure is set with a manual pump. Flow through the core is controlled by setting flow rate from hydraulic pump to accumulators.

To determine the volume of slurry required for adequate core inundation, a coreflood was performed on one core, wherein $400 \mathrm{~mL}$ of brine was injected at 20 $\mathrm{mL} / \mathrm{min}$ before $400 \mathrm{~mL}$ of $2.5 \mathrm{~g} / \mathrm{L}$ montmorillonite slurry at $20 \mathrm{~mL} / \mathrm{min}$. The coreflood effluent was sampled once per pore volume (15 mL of each $25 \mathrm{~mL}$ injected $)$. The samples were analyzed with ICP/OES to determine cation concentration in the effluent and establish a baseline volume for pre-flush and slurry injection (Fig. 4). 


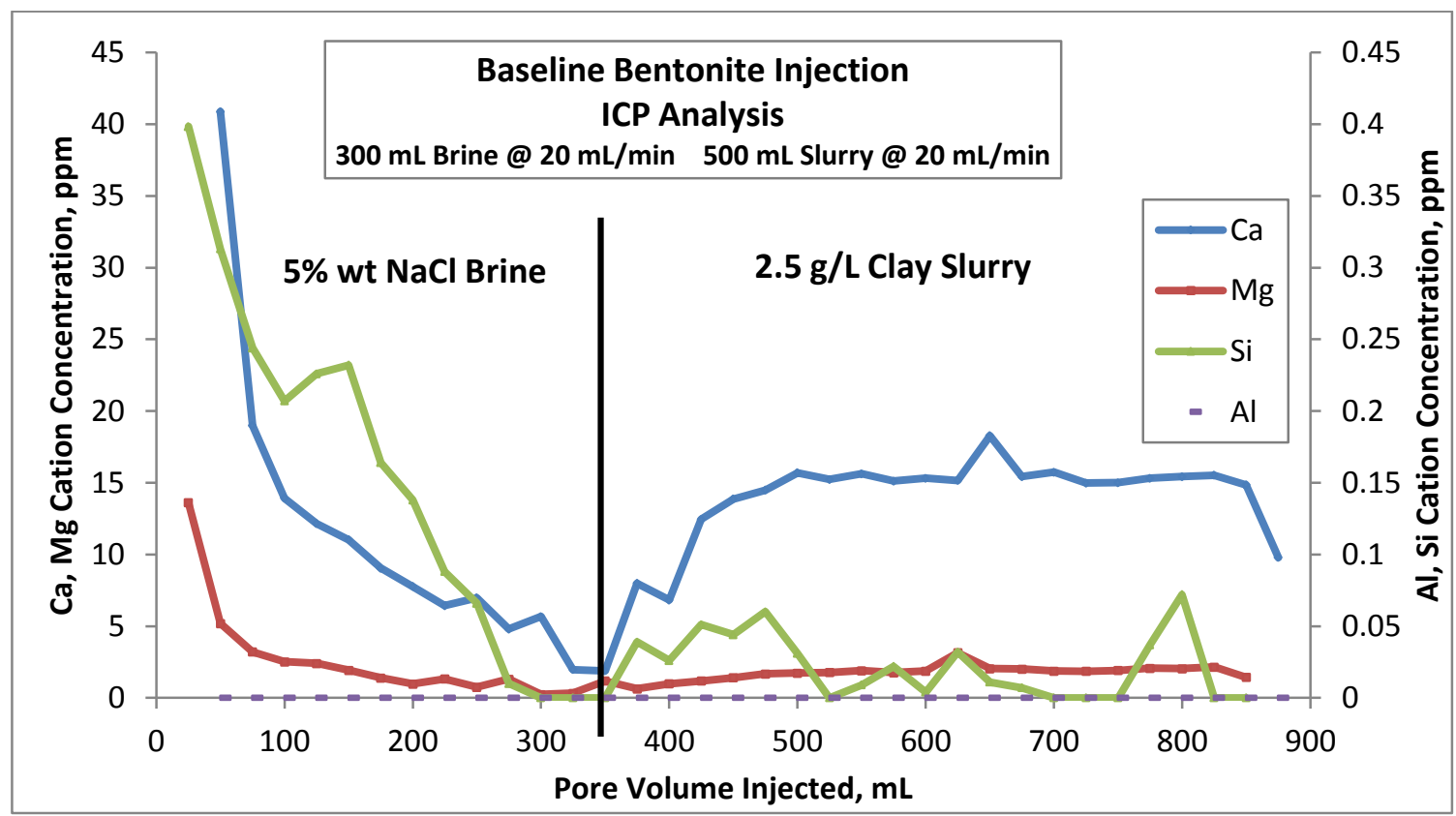

Fig. 4-Baseline ICP Analysis. This analysis of coreflood effluent from the initial slurry injection test is used to determine an effective, efficient slurry injection procedure. Excessive quantities of brine and slurry were used to determine points of diminishing returns of the flood volume for each fluid.

After considering the outcome of the baseline slurry injection, a pre-flush of 100 $\mathrm{mL} 5 \mathrm{wt} \% \mathrm{NaCl}$ brine was required, and a slurry injection of $100 \mathrm{~mL}$ of $2.5 \mathrm{~g} / \mathrm{L}$ montmorillonite was performed. Of the remaining 38 cores, two were not treated and 36 were subjected to this slurry injection. Similar to DeVine et al. (2003), flow was regulated to prevent pressure differential across the core from exceeding $300 \mathrm{psi}$. The slurry mixture for each core treatment was agitated until just before the brine injection portion of the coreflood was completed. At that time, a bulk slurry solution was removed from its stir plate, $100 \mathrm{~mL}$ was added to the treatment accumulator, the accumulator was sealed, connected, and readied to administer slurry to the coreflood. 
This minimized slurry particle settling in the accumulator. Pressure differential across each core was recorded once every 5 seconds with an automated transducer and LabView software. Effluent sampling occurred once after pre-flush and once at the end of slurry injection, for each core. As each core was removed from the coreflood apparatus, it was immersed in brine in its designated storage cell, oriented with the flood direction downward.

To confirm successful injection of montmorillonite into the cores, a test was performed to compare a slurry treated core to an untreated core. Each core was subjected to a coreflood of $200 \mathrm{~mL} 5 \mathrm{wt} \% \mathrm{NaCl}$ brine at $5 \mathrm{~mL} / \mathrm{min}$ before a shocking flood of DI water at $5 \mathrm{~mL} / \mathrm{min}$, at a temperature of $250^{\circ} \mathrm{F}$. The initial attempt at this verification was unsuccessful, due to a dysfunctional pressure collection process (Fig. 5). After repair of the pressure differential recording system, the baseline tests were resumed. Permeability was calculated with Darcy's Law, and was based on pressure readings across the core. The slurry damaged core exhibited accelerated permeability loss and confirmed effectiveness of the slurry treatment (Figs. 6 and 7). 


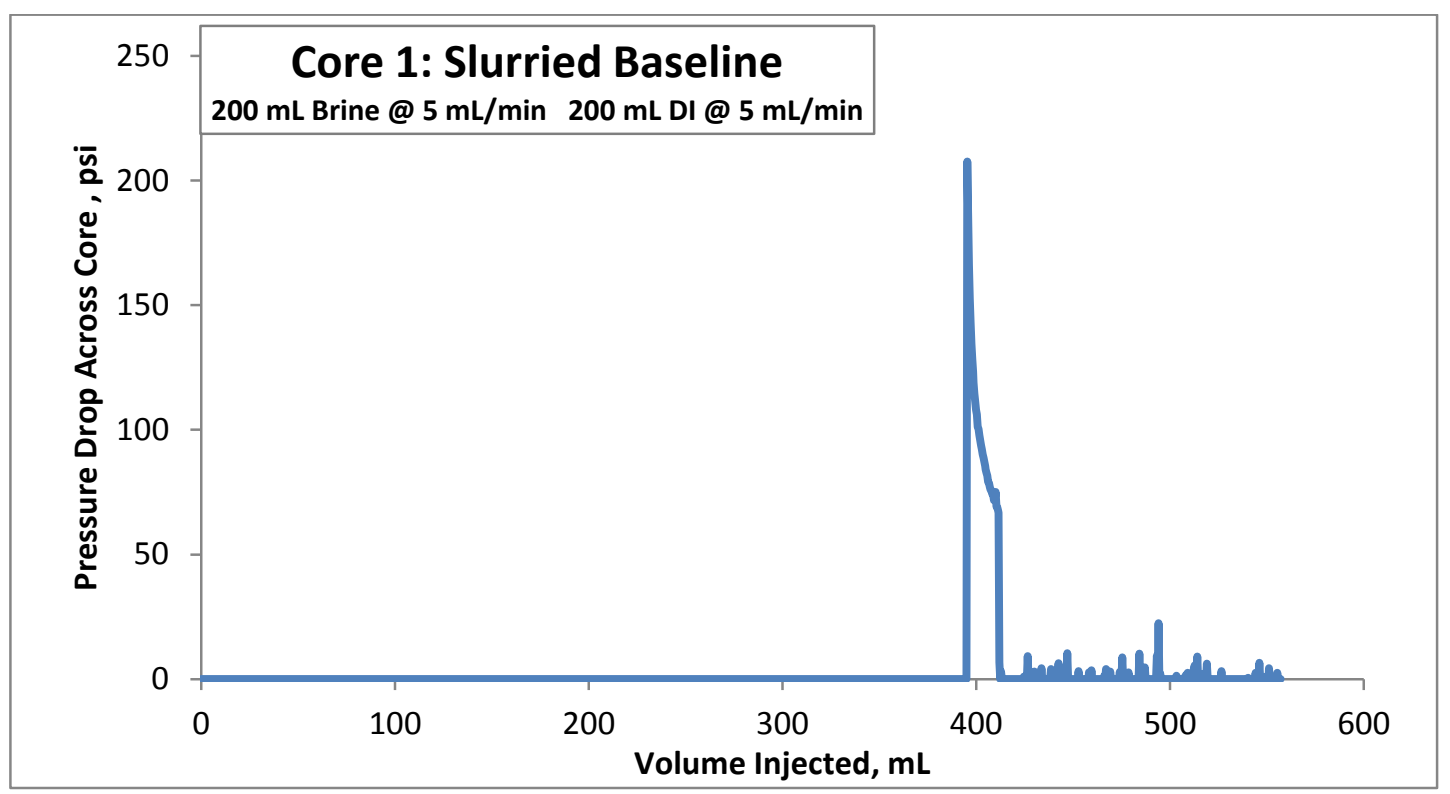

Fig. 5-Slurried Baseline. A slurried core baseline is not established, due to poor pressure recording.

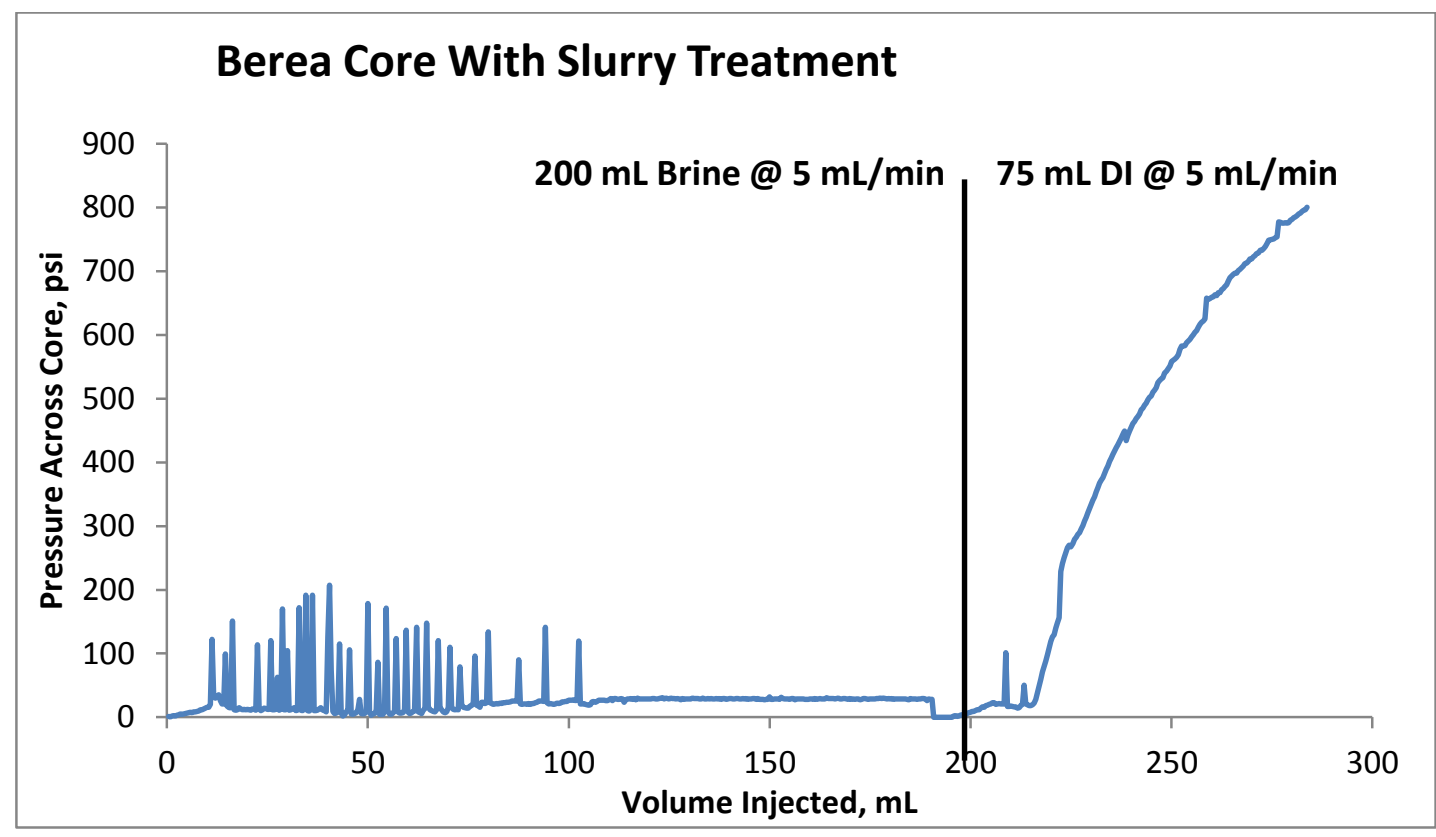

Fig. 6- Second Slurried Baseline. A slurried core baseline is successfully established. The variable peaks early in the flood are due to a new back pressure regulator which required 'breaking in'. 


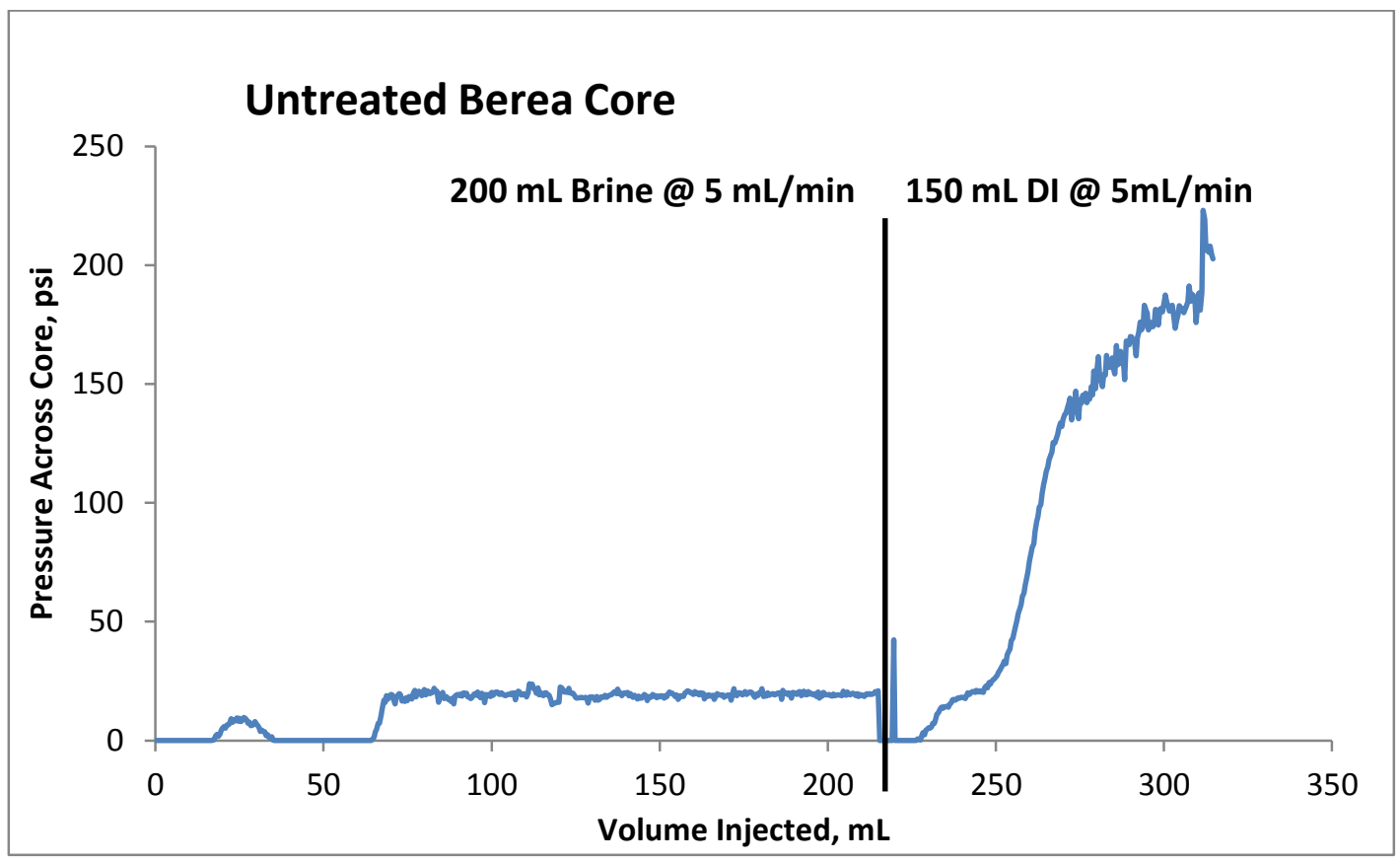

Fig. 7-Unslurried Baseline. A raw Berea core baseline is established for comparison to slurried core performance.

\subsection{Stabilizer Treatment Coreflood}

Selection of core candidates for further experimentation was determined by scrutinizing slurry injection performance. To prevent experimental error, only cores with similar slurry treatment pressure profiles were used for the stabilizer tests. The stabilizer coreflood was designed similar to El-Monier and Nasr-El-Din (2011). All cores experiments were conducted at $250^{\circ} \mathrm{F}$, to better simulate reservoir conditions. The pre-flush was $150 \mathrm{~mL}$ (6 pore volumes) of $5 \mathrm{wt} \% \mathrm{NaCl}$ brine at $5 \mathrm{~mL} / \mathrm{min}$. Stabilizer treatment was $50 \mathrm{~mL}$ (2 pore volumes) of diluted Stabilizer A at $5 \mathrm{~mL} / \mathrm{min}$. The different concentrations of Stabilizer A tested were 2 wt $\%$ Stabilizer A and 4 wt $\%$ 
Stabilizer A mixed with $5 \mathrm{wt} \% \mathrm{NaCl}$ brine. Immediately following stabilizer injection, $200 \mathrm{~mL}$ ( 8 pore volumes) of DI water was injected at $5 \mathrm{~mL} / \mathrm{min}$, in an attempt to damage the core. The experiment with $2 \mathrm{wt} \%$ Stabilizer A was conducted twice, to verify consistency of stabilizer performance. Pressure differential across the core was recorded every 5 seconds with a transducer connected to LabView. Samples of the coreflood effluent were taken twice during the pre-flush, once during stabilizer injection, and continuously during DI injection.

\subsection{Analytical Tools}

Analysis of the experiments was based on continuous pressure differential readings and on ICP/OES analysis of the coreflood effluent. Pressure readings were detected by a transducer, communicated by a Rosemount display, and recorded every 5 seconds by a computer program. Core effluent samples were filtered through 1 micron filter paper before being analyzed with the ICP/OES. The ICP/OES was calibrated with standards diluted to 5, 10, and 15 ppm for Calcium, Magnesium, Silicon, Aluminum, and Zirconium. Calibration curve $\mathrm{R}^{2}$ was acceptable only when greater than 0.9999 . 


\section{RESULTS AND DISCUSSION}

\subsection{Slurry Injection: Determination, Pressure Profiles, and Testing}

ICP/OES results of the baseline slurry injection coreflood are presented in Fig. 4. The high initial $\mathrm{Ca}$ and $\mathrm{Mg}$ concentrations are attributed to easily mobilized ions, if not actual fines from the core. The rapid decrease in $\mathrm{Ca}, \mathrm{Mg}$, and $\mathrm{Si}$ during the first $100 \mathrm{~mL}$ of brine injection is attributed to fines migration achieving a quasi-steady state. The significant decrease in cation concentration during this baseline flood occurred in the first $100 \mathrm{~mL}$ of injection. After slurry injection is initiated, cation concentration in the effluent again achieves a quasi-steady state after $100 \mathrm{~mL}$ of slurry is injected. Based on the ICP results, slurry injection of greater than $100 \mathrm{~mL}$ shows no increase in cations in the effluent.

An increase in the $\mathrm{Al}$ and $\mathrm{Si}$ was expected, if the montmorillonite fully penetrated the core. This is not evidenced in the ICP results, due to the clay not migrating fully through the core or not passing through the 1 micron filter implemented before ICP analysis. If the clay, which is greater than 1 micron in length (Trauger 1994), fully penetrated the core, the filter paper would prevent detection thereof by the ICP. This ICP analysis established parameters for injecting montmorillonite into other cores; $100 \mathrm{~mL}$ of brine was considered ample volume to stabilize a core before $100 \mathrm{~mL}$ slurry injection impregnated the core with montmorillonite.

During this specific ICP analysis, the ICP/OES machine determined that the plasma impedance exceeded its working range, and abruptly quit functioning. After 
making note of the error code displayed, the researcher took a moment to regain his pulse, verify his vitality, and notify responsible parties of the situation. It was determined, by said parties, that glass components in the plasma chamber had become soiled through routine use and required replacement. Assistance was rendered in the replacement and reconstruction of plasma chamber components. Afterward, the ICP was recalibrated and analysis of samples repeated.

The 36 cores subjected to slurry injection exhibited varying degrees of pressure increase across the core, at various rates. Figs. 8 through 10 present selected examples of pressure differential curve types observed during slurry injection. The point at which brine injection is terminated for slurry injection is identifiable by a dip in the middle of each of these pressure profiles; the slurry mixture was not under pressure when injection initiated, so the treatment accumulator robbed pressure from the system. In Figs. 8a and $8 \mathrm{~b}$, the increase in pressure across the core indicates rapid permeability loss attributable to filter cake. This occurred with 16 of the 36 cores (44\%). The core 27 (Fig. 8b) slurry injection was terminated prematurely because permeability could not be recovered by restricting flow. The pressure curves in Figs. 9a and 9b indicate less drastic permeability loss and are typical to $36 \%$ of the slurry injection profiles. The small peak in Fig. 9a at $140 \mathrm{~mL}$ is attributed to degradation of filter cake and continued slurry injection. Figs. $10 \mathrm{a}$ and $10 \mathrm{~b}$ are typical of $17 \%$ of the slurry injection profiles; these cores were selected for further experimentation. As the $2.5 \mathrm{~g} / \mathrm{L}$ montmorillonite slurry was injected, permeability loss was gradual. The lack of abrupt peaks in Figs. 10a and 10b indicate that filter cake accumulation was slow if non-existent. 


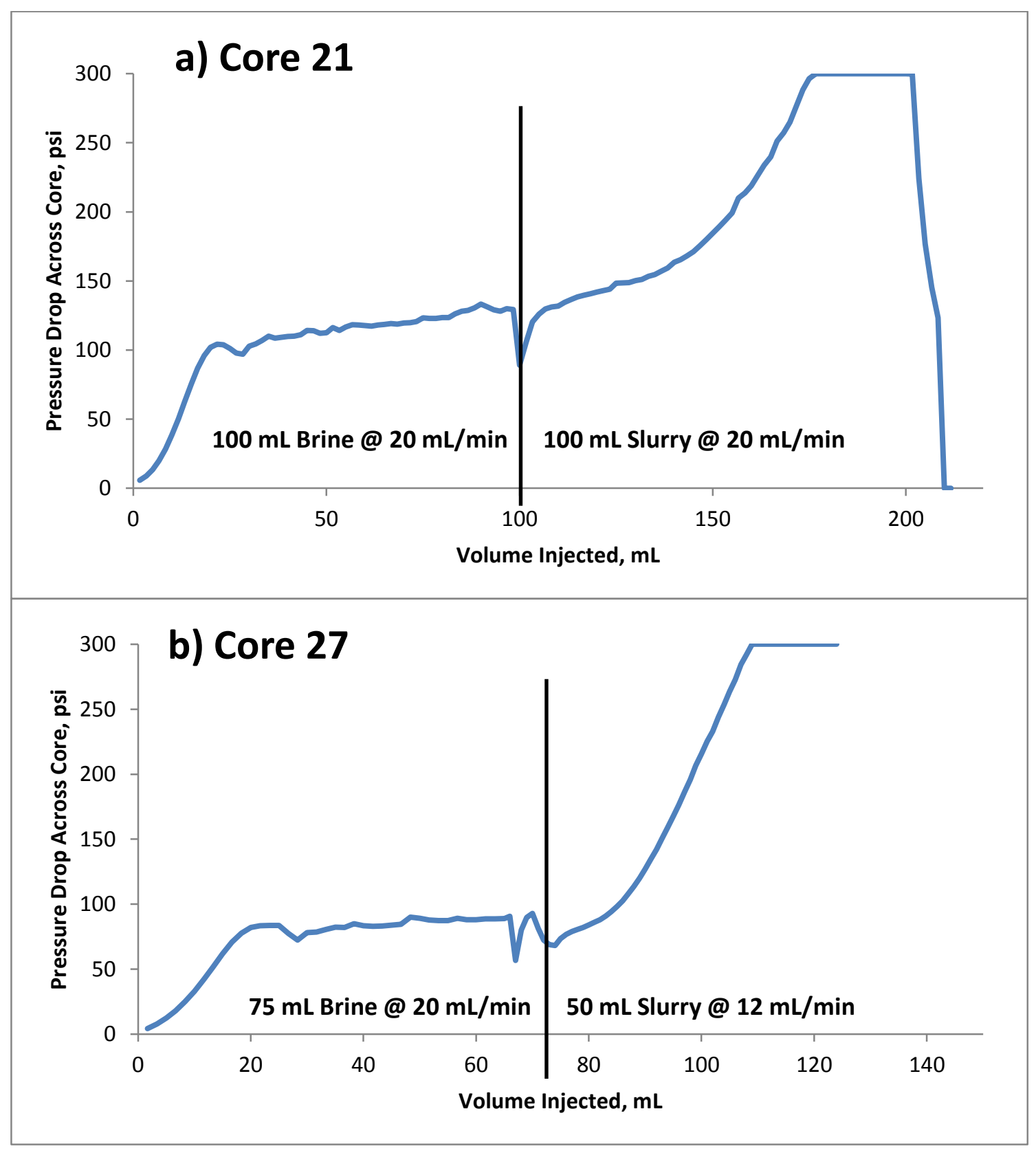

Fig. 8-Poor Slurry Profiles. These cores suffered rapid permeability loss during slurry injection due to filter cake development. a) This curve is typical to $44 \%$ of the slurry injection attempts. b) This injection was arrested due to excessive permeability loss despite flow control. 


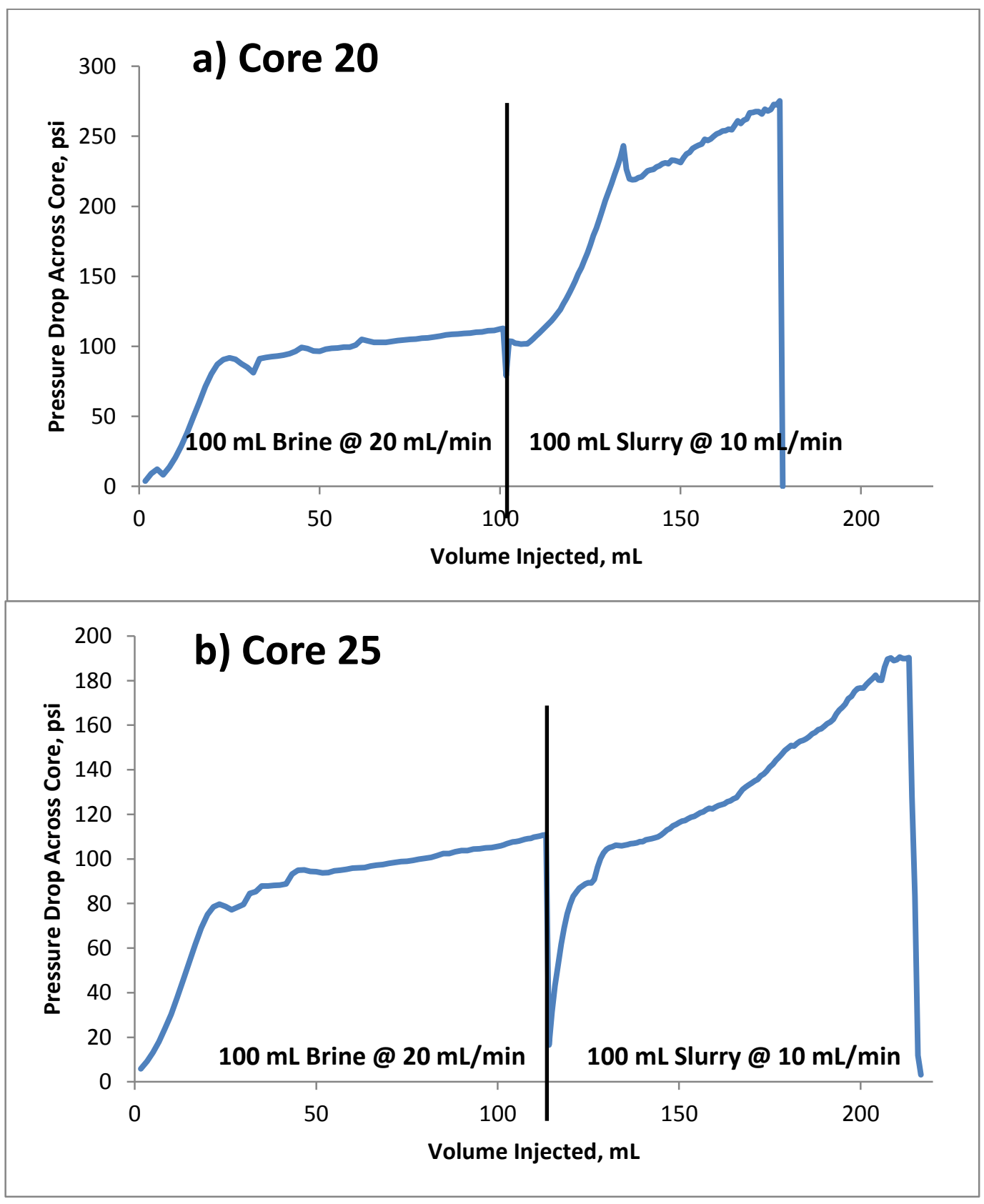

Fig. 9-Adequate Slurry Profiles. These cores exhibited greater permeability loss than Figure 8, and were selected for non-critical experimentation. a) The peak at $140 \mathrm{~mL}$ suggests a filter cake that deteriorated and allowed slurry penetration into the core matrix. b) Exhibits a higher rate of permeability loss than other cores. 


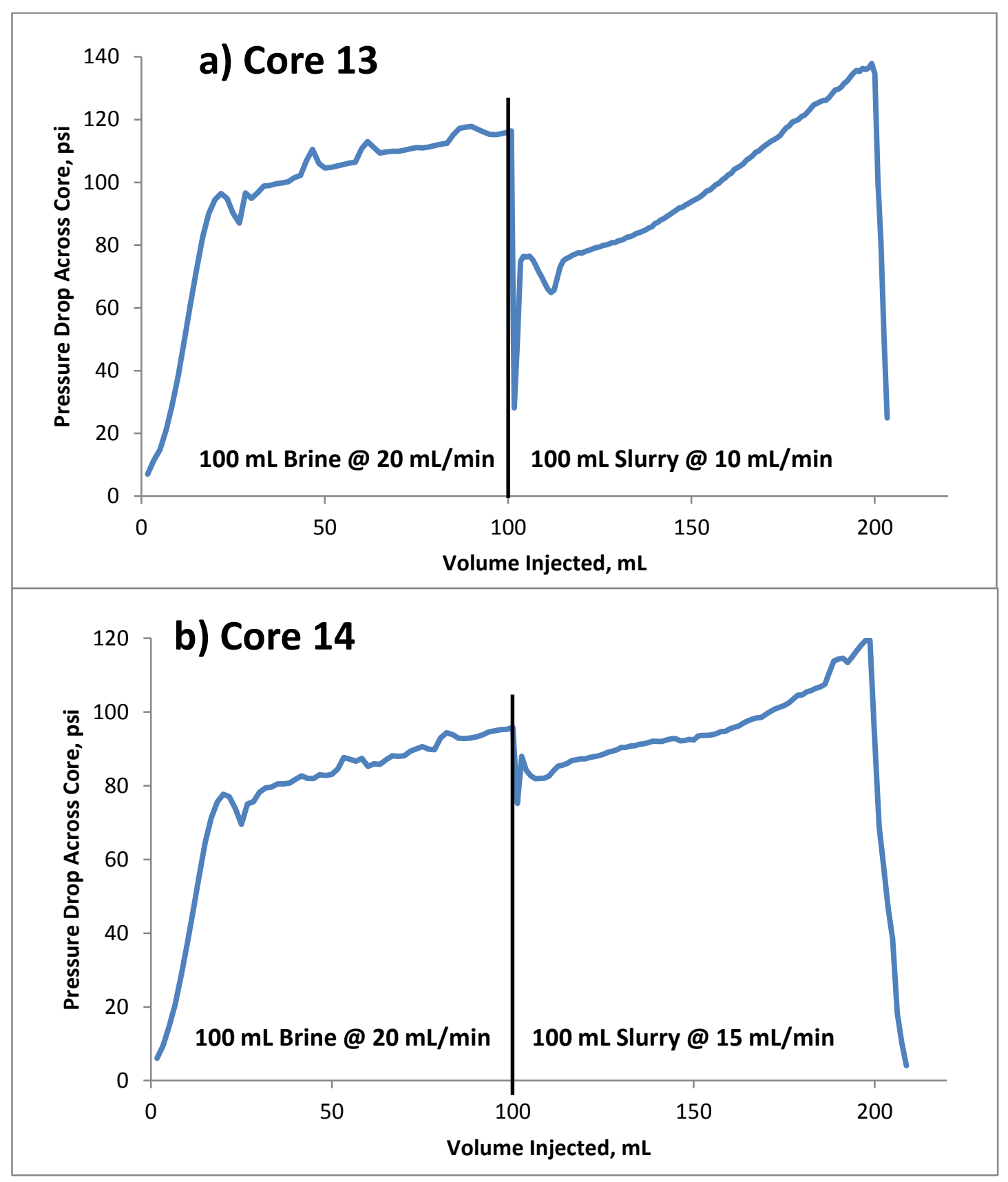

Fig. 10 - Good Slurry Profiles. These slurry injections exhibited less permeability loss during slurry injection than most. This indicates internalization of the montmorillonite slurry instead of filter cake buildup. a) Core selected for use with the $2 \%$ Stabilizer A experiment. b) Core selected for use with the $4 \%$ Stabilizer A experiment. 
The ICP/OES cannot verify success of the slurry injection. Therefore, a slurried core and an unslurried core were subjected to damaging corefloods. The pressure profiles for this test, Figs. 11a and 11b, indicate a significant difference between these cores. Pressure drop across the slurried core is four times that of the untreated core after comparable fluid injection. Each core achieved a similar steady state pressure drop during brine injection; only after the DI shock did the difference in performance occur. It was expected that fines migration would contribute to an increased pressure drop. The excess increase in the slurried core is attributed to swelling montmorillonite, as montmorillonite swelling would occur before migration. Fig. 11b also provides a background against which stabilizer performance can be determined.

This coreflood (Fig 11b) was not easily prosecuted: During the first attempt, oil was observed on the core after it was inserted into the core holder. The overburden pressure sleeve had ruptured during previous experimentation and leaked hydraulic oil into the core chamber. When the sleeve was removed for replacement, about $20 \mathrm{~mL}$ of black sludge was cleaned from the confining pressure system. It is assumed that various chemicals from various experiments had penetrated the pressure sleeve over time, and had reacted with the hydraulic oil. Because the overburden pressure system is closed, the oil was not regularly cycled through the confining pressure chamber. Additionally, the abundance of peaks early in the brine flush (Fig. 11b) were caused by the back pressure regulator of the coreflood apparatus. Over time, effluent had eroded the metal contact point of the diaphragm and regulator chamber. The regulator was rebuilt with a newly machined bottom chamber and the old Teflon diaphragm. The diaphragm fit 
more snugly in the new base and would allow only bursts of effluent through. Within 20 minutes of operation, the diaphragm stabilized and provided constant back pressure.

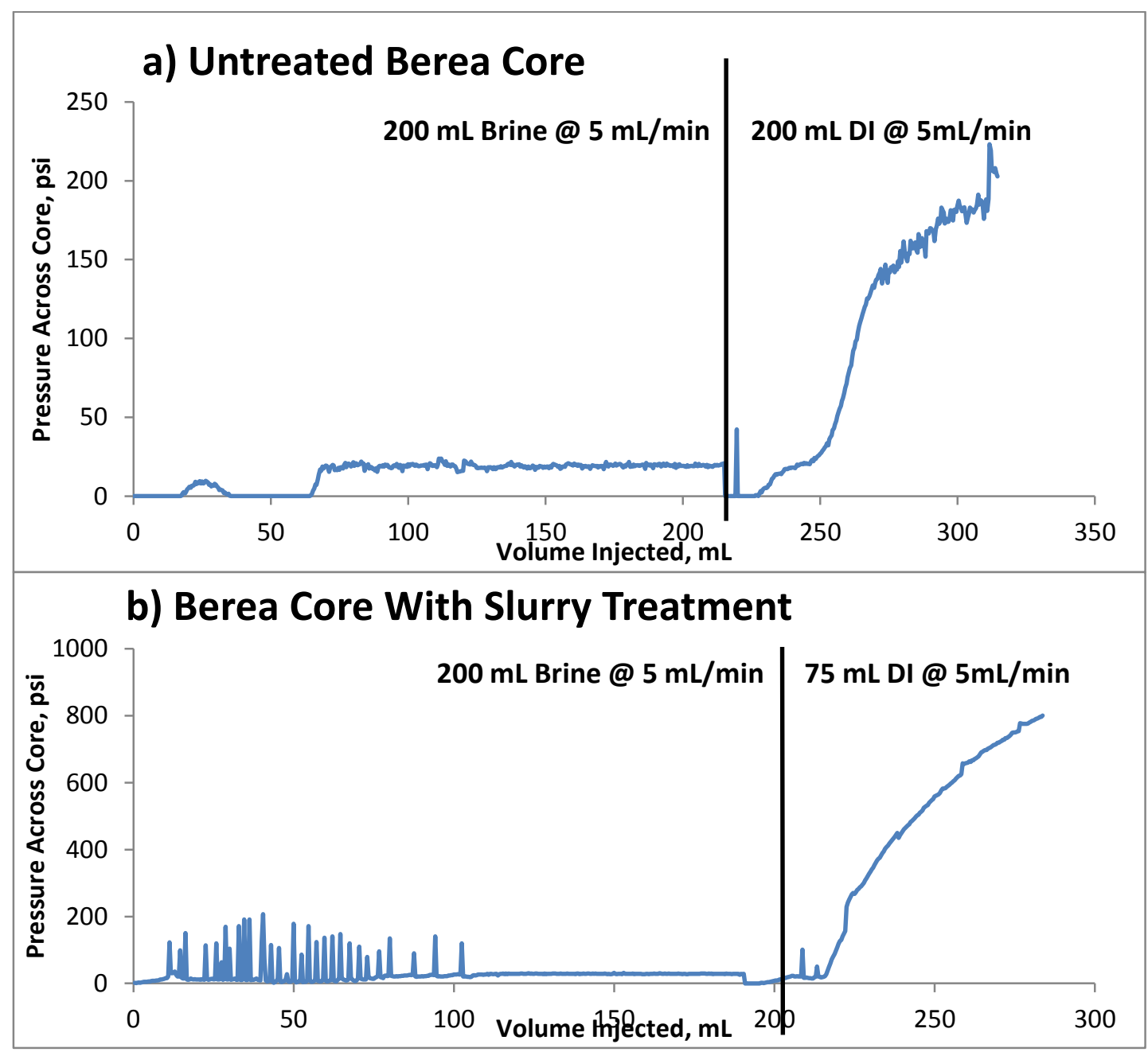

Fig. 11 - Slurry Verification. Intentional damage is incurred on a slurry treated and untreated core to verify viability of slurry injection scheme. 


\subsection{Stabilizer Treatment Pressure Profiles}

Cores which exhibited limited pressure increase during slurry injection were selected for the stabilizer experiments. Stabilizer solutions were diluted in $5 \mathrm{wt} \% \mathrm{NaCl}$ brine, to coincide with the fluid used for pre-flush in the coreflood. The pressure profile for the $2 \mathrm{wt} \%$ Stabilizer A treatment coreflood is shown in Fig. 12. The brine injection pre-flush established a steady pressure drop for permeability measurement. After stabilizer injection, the pressure varies briefly before steadying out during the DI shock. The pressure across the core is slightly higher after stabilizer application, but much lower than that of the baseline slurried core (Fig. 11b). It is possible that the stabilizer caused montmorillonite platelets to flocculate but not adhere to pore walls. This could result in stabilized fines clogging pore throats. No distinct characteristics are discernible in the pressure profile for the $2 \mathrm{wt} \%$ stabilizer injection, suggesting a consistent coreflood. 


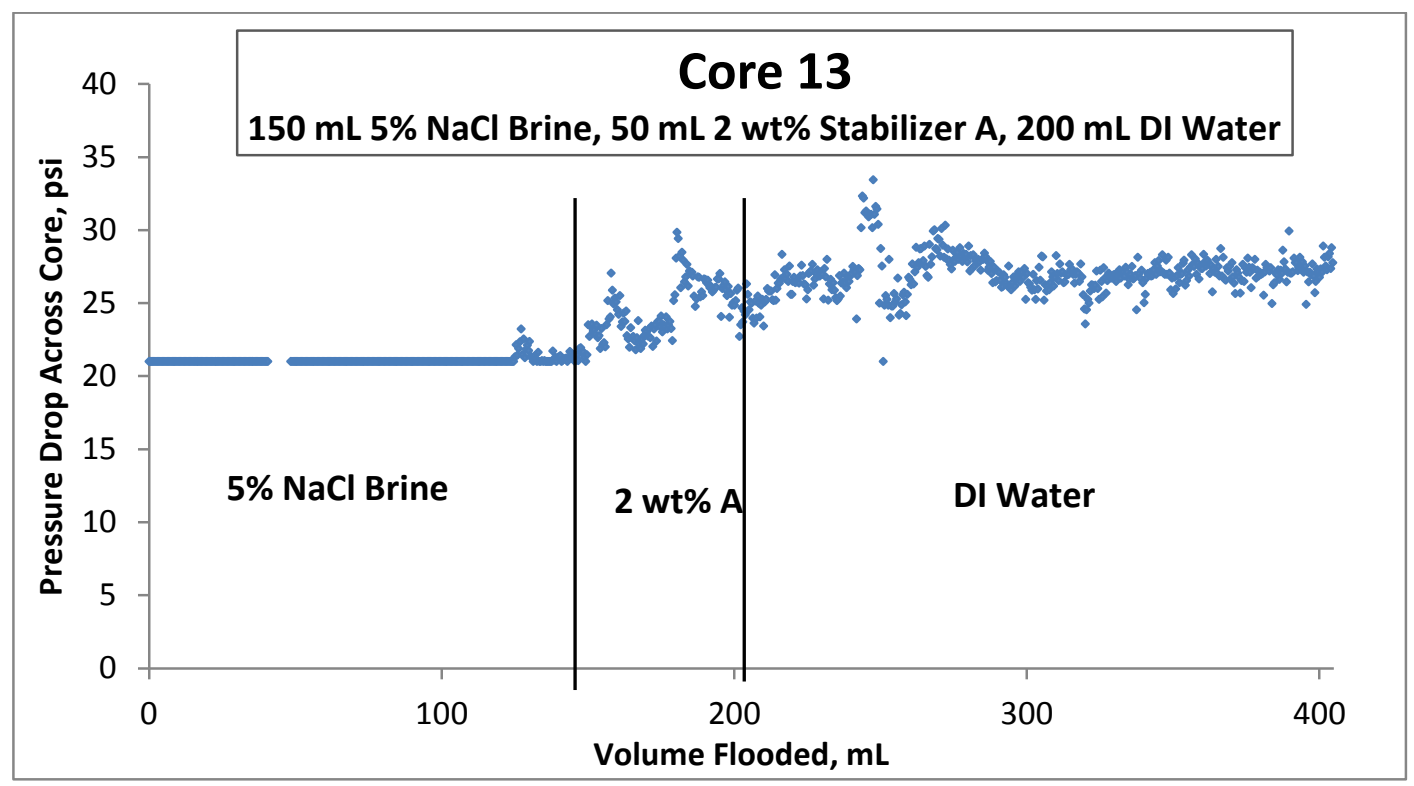

Fig. 12 - 2 wt $\%$ Stabilizer A. Application of $2 \mathrm{wt} \%$ Stabilizer A prevented damage from both swelling clay and fines migration.

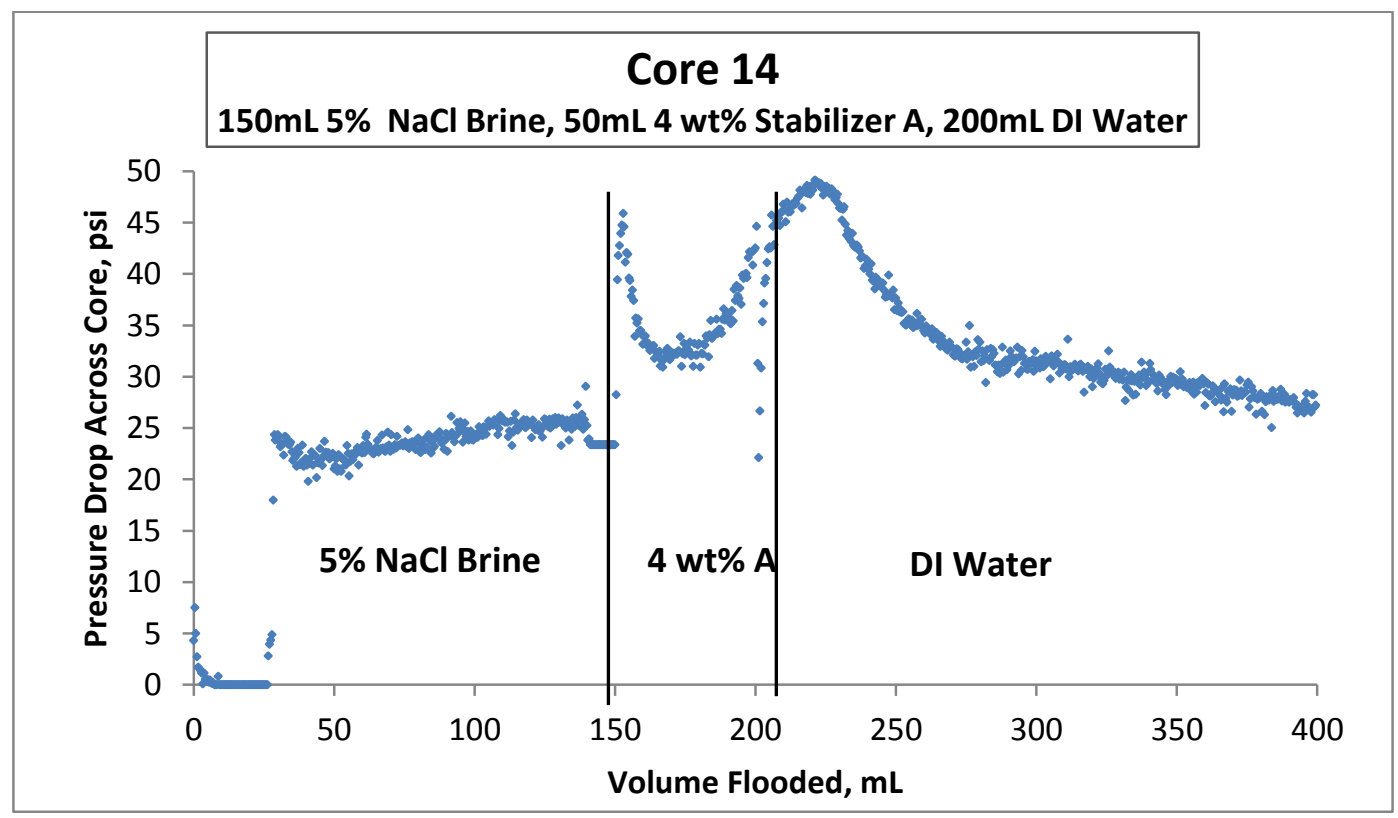

Fig. 13- 4 wt $\%$ Stabilizer A. Application of $4 \mathrm{wt} \%$ Stabilizer A resulted in temporary pressure increase due to higher viscosity. As the core was shocked with DI, pressure dropped, indicating regained permeability. 
Performance of the stabilizer at higher concentration proved successful as well, and the pressure curve for this coreflood, Fig. 13, exhibited some unique characteristics. The stabilizer solution was $4 \mathrm{wt} \%$ Stabilizer A: twice that of the previous test. The peak at $150 \mathrm{~mL}$ was caused by human error: An attempt was made to pressurize the treatment accumulator prior to injection, and resulted in briefly over-pressurizing the system. Pressure across the core increased slightly during stabilizer injection due to higher viscosity of the Stabilizer A solution. When stabilizer injection was terminated, and the DI shock initiated, pressure across the core dropped quickly and continued to decline through the DI injection. This higher concentration stabilizer treatment better prevented permeability loss, despite achieving a higher maximum pressure drop during stabilizer injection. The final pressure difference after each stabilizer treatment was about the same; the initial pressure difference for the $2 \mathrm{wt} \%$ run was lower than the $4 \mathrm{wt} \%$, due to core characteristics. Permeability loss of the experimental cores is presented in Table 3, and is dependent upon the characteristics of injected fluids in Table 4. 
Table 3-Permeability Comparison. Values are based on pressure drop across the core, and are calculated with Darcy's Law.

\begin{tabular}{|c|c|c|c|}
\hline \multicolumn{4}{|c|}{ Permeability Losses } \\
\hline Coreflood & Before, $k_{\circ}(m D)$ & After, $\mathrm{k}(\mathrm{mD})$ & $\mathrm{k} / \mathrm{k}_{\mathrm{o}}$ \\
\hline Untreated Core & 85 & 9.3 & 0.109 \\
\hline Slurried Core & 61 & 2.2 & 0.036 \\
\hline 2 wt $\%$ Stabilizer A & 81 & 63 & 0.778 \\
\hline 4 wt\% Stabilizer A & 68 & 59 & 0.868 \\
\hline \multicolumn{4}{|c|}{ Darcy's Law } \\
\hline \multirow{6}{*}{$k=$} & \multicolumn{3}{|c|}{$k=$ Permeability, Darcy } \\
\hline & & \multirow{2}{*}{\multicolumn{2}{|c|}{$\begin{array}{l}Q=\text { Flow Rate }, \mathrm{cm}^{3} / \mathrm{sec} \\
\mu=\text { Viscosity }, \text { centipoise }\end{array}$}} \\
\hline & & & \\
\hline & & \multicolumn{2}{|c|}{$\Delta L=$ Length, $\mathrm{cm}$} \\
\hline & & \multicolumn{2}{|c|}{$\Delta P=$ Pressure Change, atm } \\
\hline & & \multicolumn{2}{|c|}{$A=$ Crossection Area, $\mathrm{cm}^{2}$} \\
\hline
\end{tabular}

Table 4-Coreflood Fluid Characteristics. Density and viscosity of the various fluids injected during coreflood.

\section{Coreflood Fluid Characteristics}

$\begin{array}{ccc}\text { Liquid } & \text { Viscosity @ 80 } 0^{\circ} \text {, centipoise } & \text { Density @ } 80^{\circ} \mathrm{F}, \mathrm{g} / \mathrm{cm}^{3} \\ 5 \text { wt\% NaCl Brine } & 1.05 & 1.038 \\ 2 \text { wt\% Stabilizer A in 5 wt\% NaCl } & 1.08 & 1.052 \\ 4 \text { wt\% Stabilizer A in 5 wt\% NaCl } & 1.05 & 1.053 \\ \text { DI Water } & 0.95 & 0.999\end{array}$




\subsection{Stabilizer Treatment ICP/OES Profiles}

During each stabilizer treatment, two coreflood effluent samples were drawn during brine injection and one sample per pore volume was drawn during stabilizer injection and DI shock. The samples drawn during brine injection established background cation concentration in the effluent against which stabilizer performance could be compared. The results of these analyses are presented in Figs. 14a and 14b and Figs. 15a and 15b for 2 wt $\%$ Stabilizer A and 4 wt $\%$ Stabilizer A, respectively. All concentrations are plotted on the same axis in parts a; parts b use a second axis to expose the curves of low concentration ions. Each stabilizer concentration fully penetrates the core and contributes to a high $\mathrm{Al}$ concentration immediately after injection. At both stabilizer concentrations, a peak in $\mathrm{Zr}$ follows the $\mathrm{Al}$ peak, though at much lower concentrations. The greater charge of $\mathrm{Zr}$ allows it to interact more readily with clays in the core and remain in place more easily than $\mathrm{Al}$, hence the earlier and greater peak in Al. During the $2 \mathrm{wt} \%$ Stabilizer A test, dual peaks in the $\mathrm{Ca}$ and $\mathrm{Mg}$ concentrations are observed after stabilizer injection and before the $\mathrm{Al}$ peak. This could be attributed to the two stabilizer cations, $\mathrm{Al}$ and $\mathrm{Zr}$, displacing $\mathrm{Ca}$ and $\mathrm{Mg}$ in the core at different rates. ElMonier and Nasr-El-Din observed similar bimodal peaks in $\mathrm{Ca}$ and $\mathrm{Mg}$ during previous experiments with Stabilizer A, suggesting that this is not dependent on smectite in the core. 


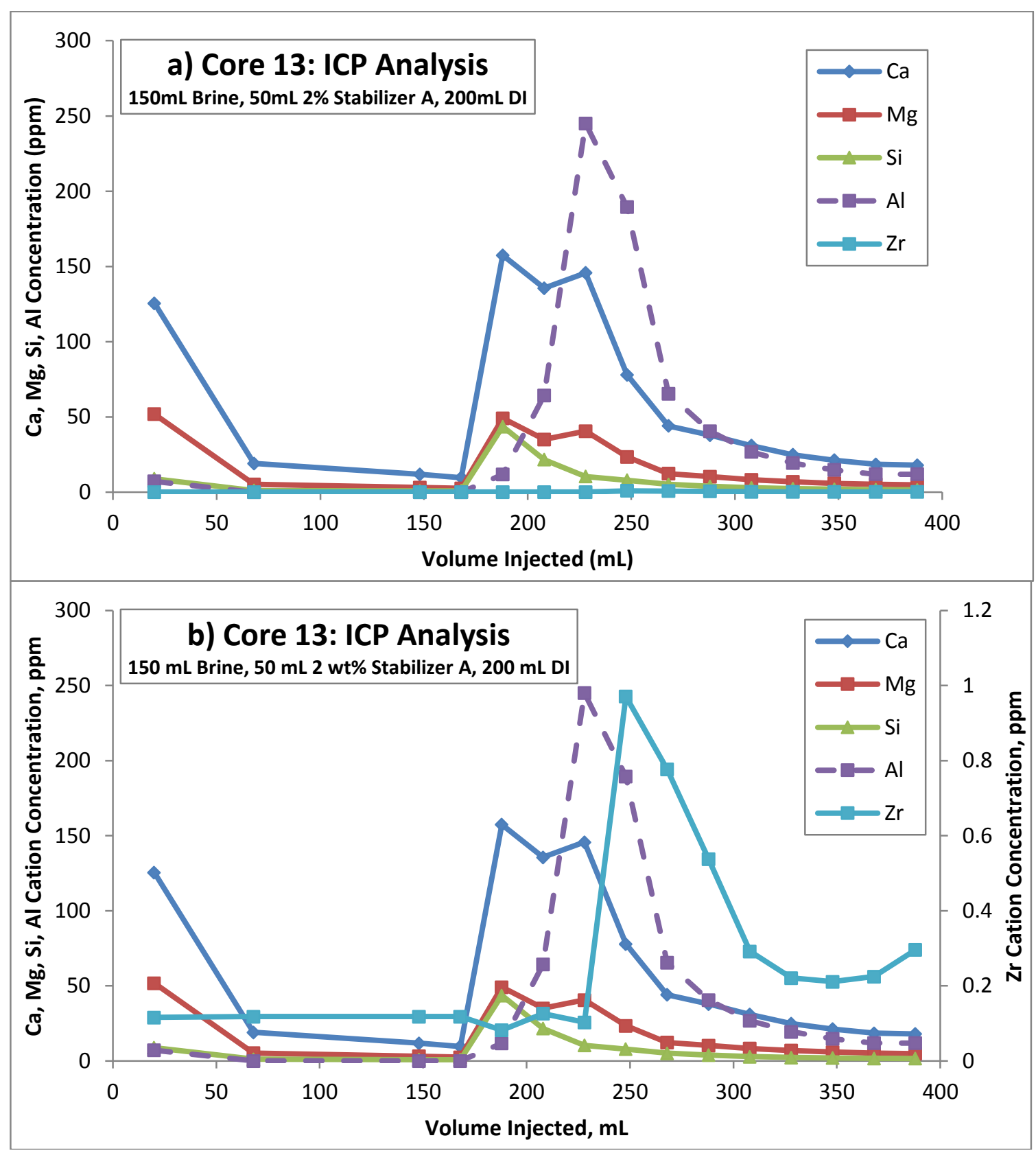

Fig. 14-2 wt\% Stabilizer A ICP. Stabilizer injection commenced at 150 $\mathrm{mL}$, after brine injection stabilized the cation concentration. a) uses a single axis while b) uses a second vertical axis to expose the $\mathrm{Zr}$ curve. 


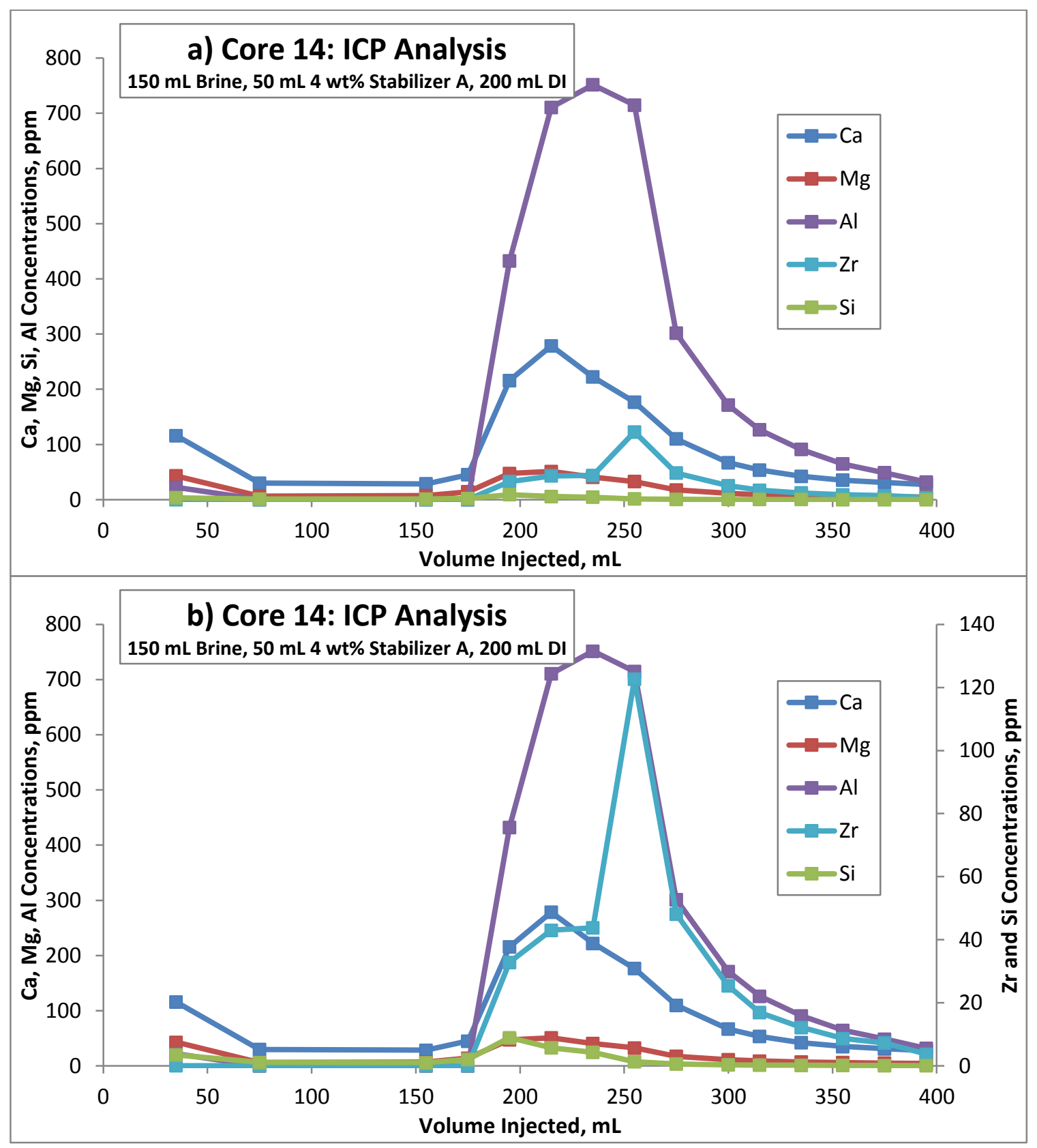

Fig. 15- 4 wt\% Stabilizer A ICP. Stabilizer injection commenced at 175 $\mathrm{mL}$, after brine injection stabilized the cation concentration. a) uses a single axis while b) uses a second vertical axis to expose the $\mathrm{Zr}$ and $\mathrm{Si}$ curves. 

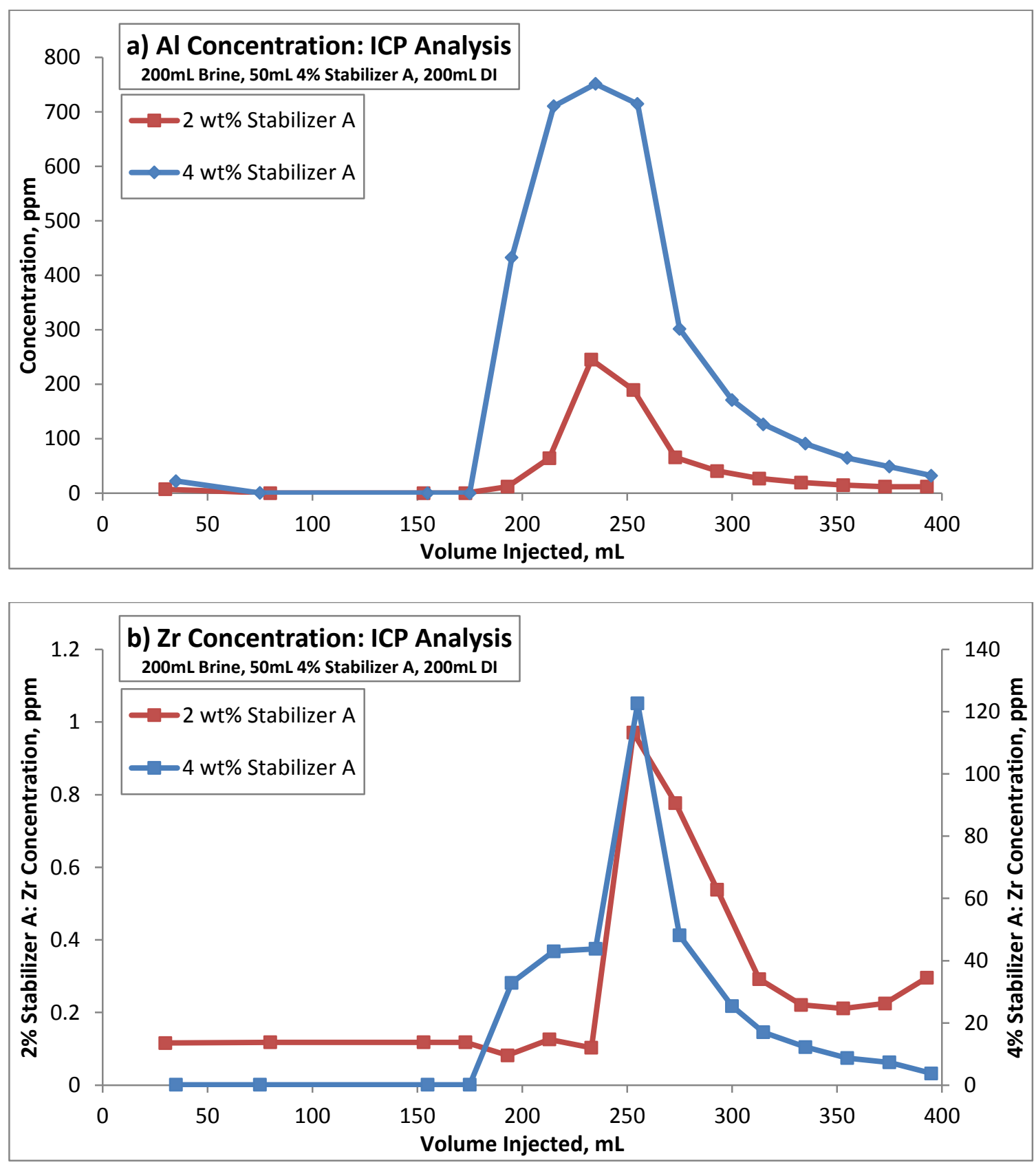

Fig. 16-ICP/OES values presented by element. The concentrations of each element are presented independently for comparison of effluent of the two stabilizer treatments. 

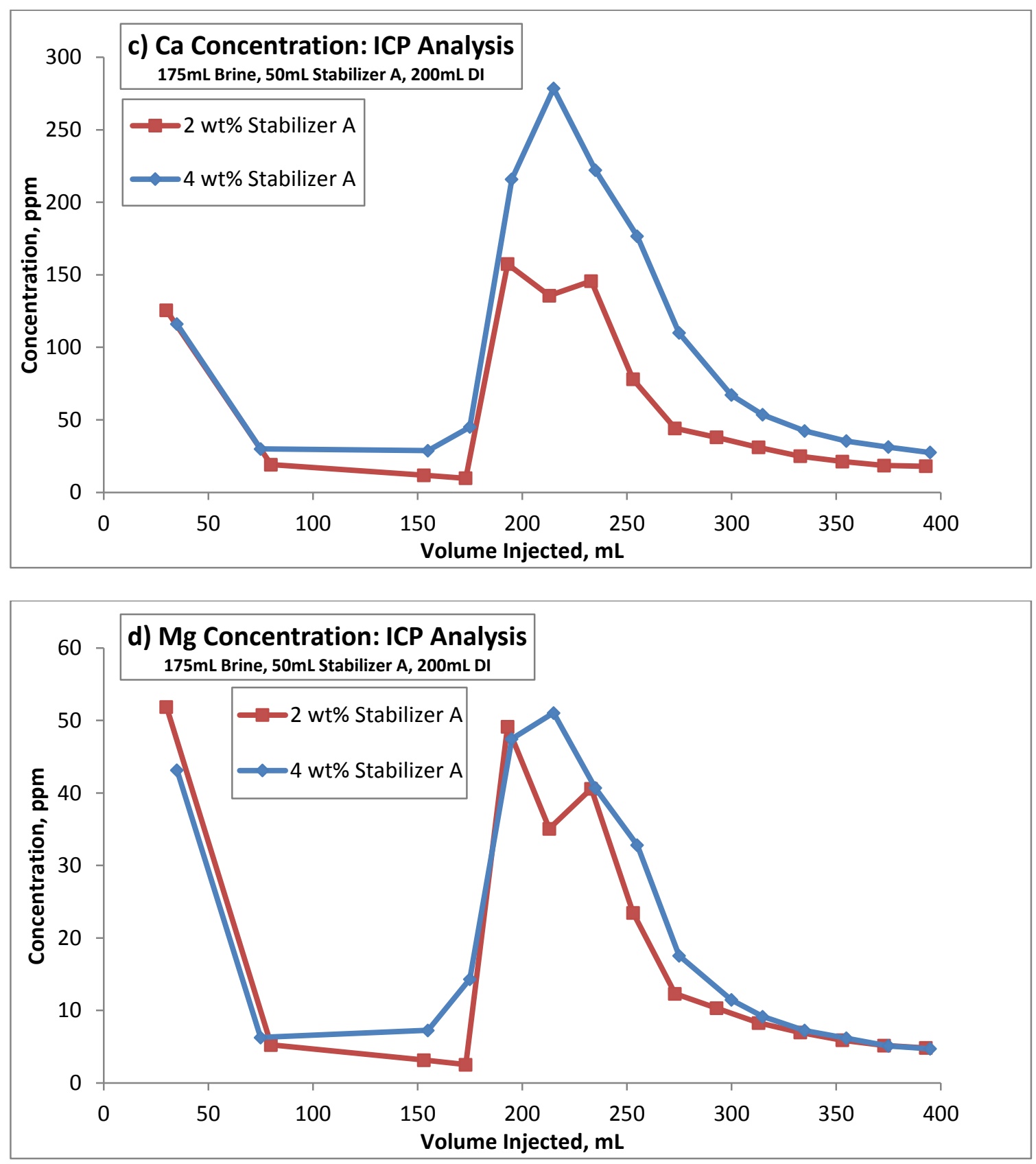

Fig. 16 Continued 


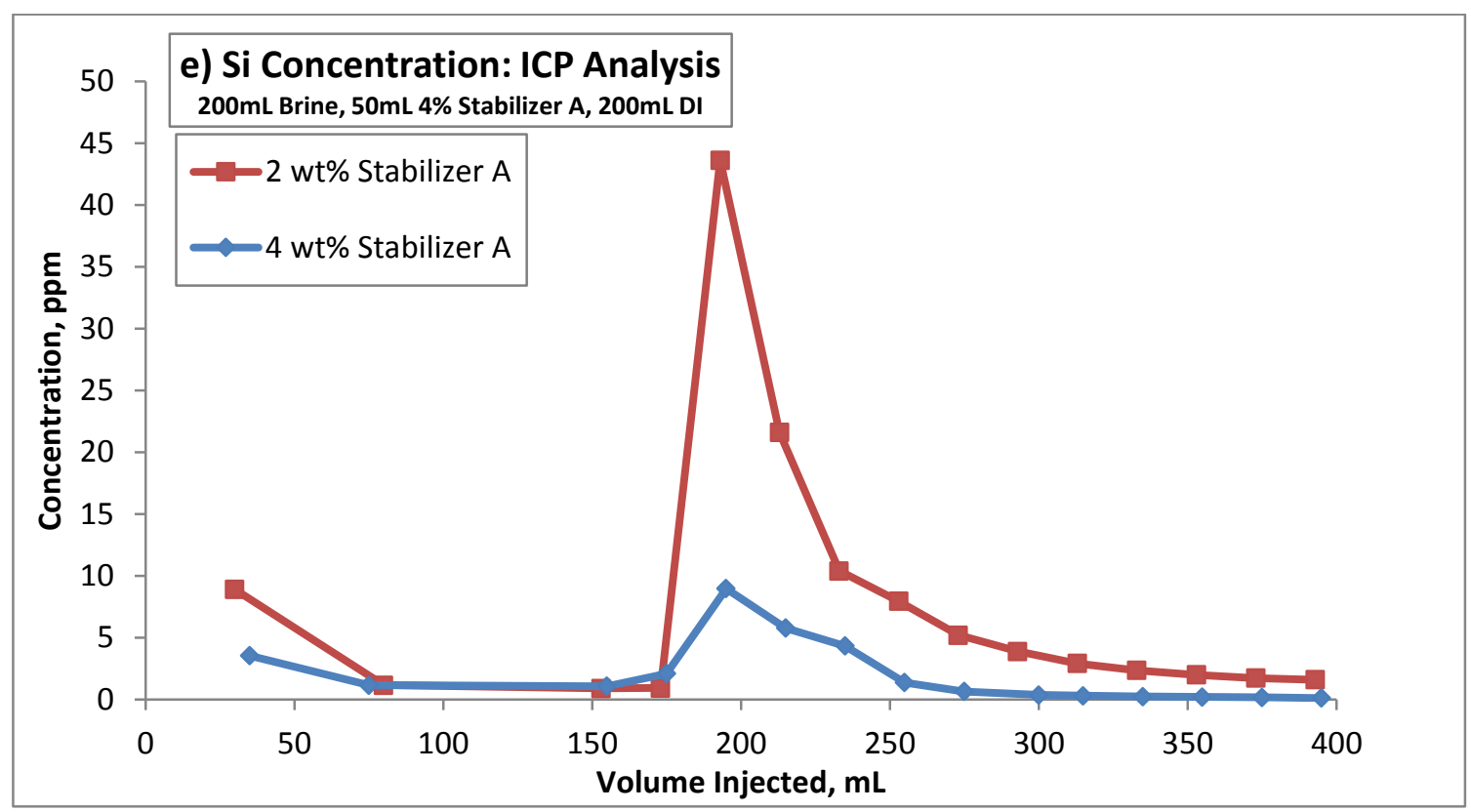

Fig. 16 Continued

Cation concentrations are presented by element in Figs. 16a through 16e. The 4 wt\% Stabilizer A coreflood produces consistently higher cation concentrations in the effluent. This is expected for $\mathrm{Al}$ and $\mathrm{Zr}$ (Figs. 16a and 16b) due to the greater stabilizer concentration injected. The difference for $\mathrm{Mg}$ and $\mathrm{Ca}$ (Figs. 16c and 16d) is attributed to the higher concentration of cations in the $4 \mathrm{wt} \%$ run displacing weaker cations from within the core. Peaks in Si occur for both tests after stabilizer injection (Fig. 16e), but are 4 times greater during the $2 \mathrm{wt} \%$ run. This is attributed to migration of un-stabilized fines to the effluent. The $4 \mathrm{wt} \%$ stabilizer more aggressively arrested these fines, preventing Si from mobilizing through the effluent. 


\subsection{CT Scan Comparisons}

To better identify the influence of Stabilizer A on the pore space of the cores, a computerized tomography (CT) scan was conducted. After being flooded with Stabilizer A, the Berea core matrix is modified and causes a higher CT number, Fig. 17, during the scan. This is attributed to the structure established as a result of cationic interaction with the clays in the matrix. Porosity is calculated from the CT scan by dividing the difference in CT number between saturated sample and dry sample by the difference in CT number between the saturating fluid and air. Porosity calculations suggest that Stabilizer A has a beneficial influence on the smectite damaged cores, Fig. 18, which results in a porosity improvement of about $20 \%$. An increase in porosity does not imply an increase in permeability; as more of each pore is opened, connectivity thereof could become more limited. It is assumed that Stabilizer A interacts with both clay and the pore walls, so as the clay is secured against the pore walls, more void space is available. This causes slight buildup in the pore throats as well, which could decrease permeability, but not to the degree caused by fines migration. 


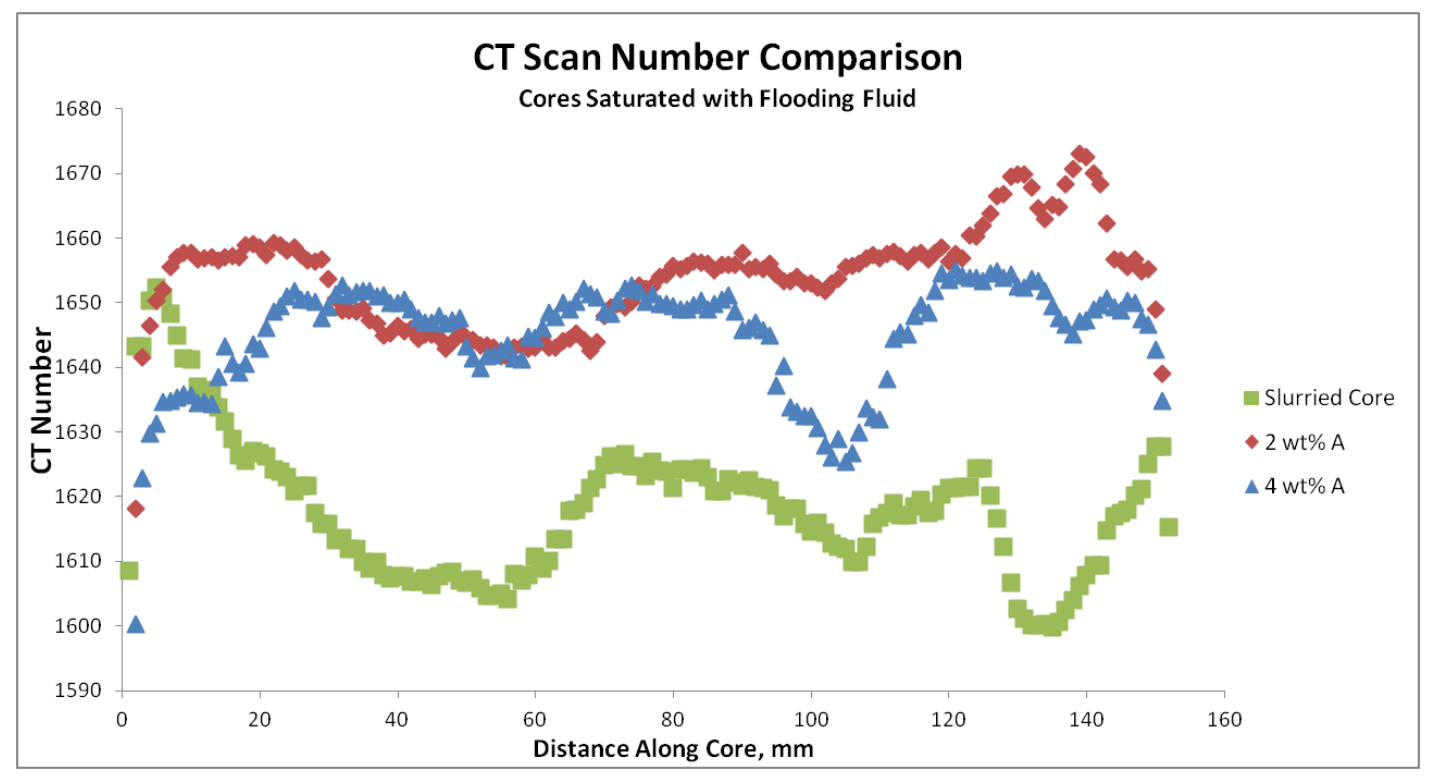

Fig. 17-CT Scan Number Comparison. The influence of Stabilizer A in the core matrix results in a higher $\mathrm{CT}$ number.

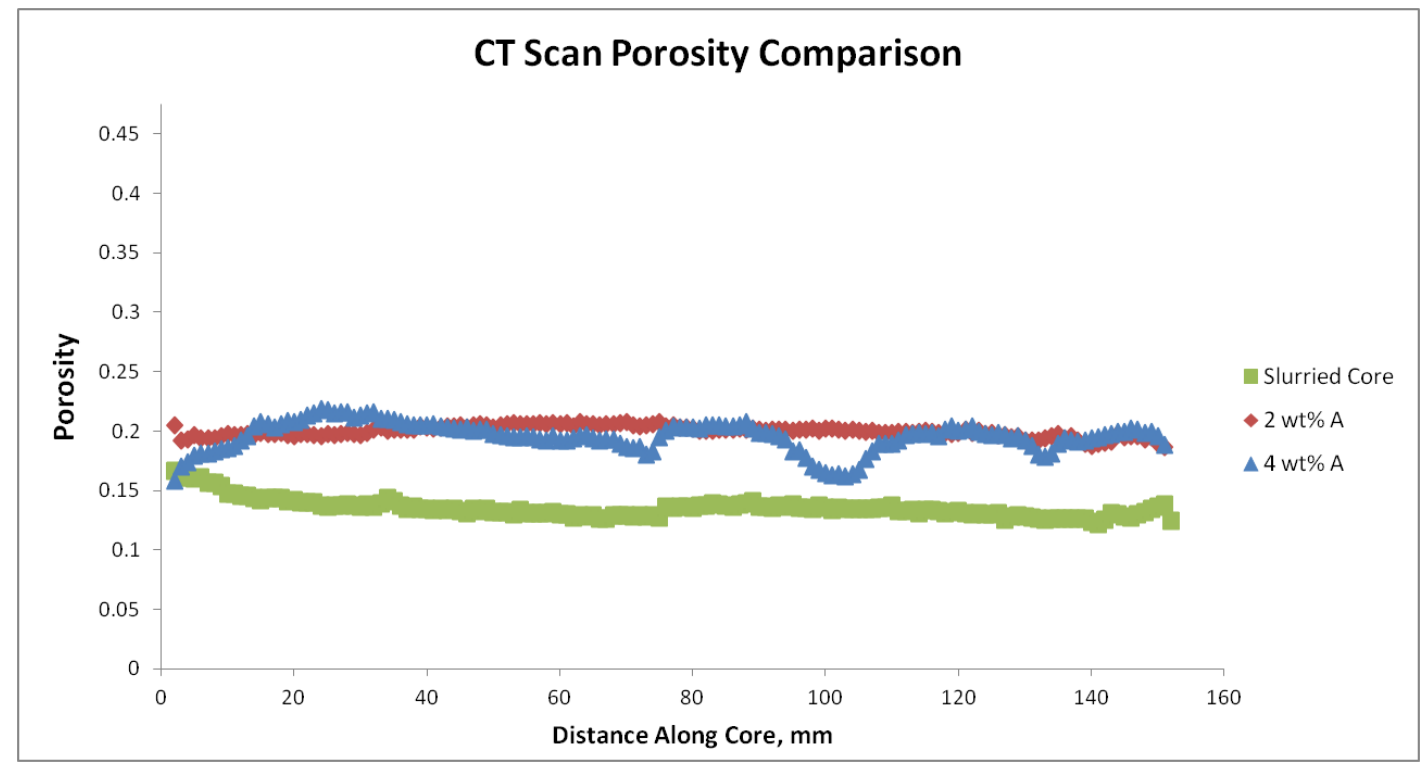

Fig. 18 - CT Scan Porosity Comparison. Cores flooded with Stabilizer A show a higher porosity as a result of the treatment. This is attributed to the strong, multiple electrostatic bonds occurring between the stabilizer and the clay. 


\subsection{Experimental Error}

During the course of these experiments, attempts to maintain a sterile and consistent laboratory environment were not always successful. Additionally, some aspects of the experiment introduced error. The coreflood apparatus is a fragile system dependent on at least six subsystems. Problems occurred with the backpressure regulator, accumulators, confinement sleeve, and tubing.

When coreflood pressures approached 1000 psi, the backpressure regulator lost effectiveness and would vary between 600 and 1000 psi. This was not a significant source of error because analytical pressure readings were of the difference across the core, but it was an unexpected irregularity.

The pressure transducer was able to measure 1 to $1000 \mathrm{psi}$, and at pressures lower than 30 psi, the signal was not sufficient for LabView to interpret. When the pressure across the core was less than $30 \mathrm{psi}$, measurements were manually recorded. At low pressures, the readings were fairly constant, allowing for accurate manual recording.

Before analysis by the ICP, samples were filtered with 1 micron filter paper. This is a similar size to the length of most clay platelets, and likely removed pertinent elements from the effluent samples.

Slurry penetration into the core was not specifically determined. Its presence was confirmed, but the extent thereof is uncertain. It is possible that varying quantities of montmorillonite were injected into the various cores. 


\subsection{Further Study}

Further research should focus on the performance of Stabilizer A in a smectiterich core under varying temperatures and $\mathrm{pH}$ conditions. While it is assumed, based on El-Monier and Nasr-El-Din (2011), that Stabilizer A will perform well in extreme $\mathrm{pH}$ environments, validation of its effect on swelling clays would be beneficial.

A comparison of the performance of different types of clay stabilizers in smectite rich cores will establish which stabilizing mechanism is best suited to swelling clays. These experiments should be conducted in varying temperature and $\mathrm{pH}$ environments.

Repeating this experiment with a flow-back factor will better simulate the effect of Stabilizer A as an additive to completions fluids. If the distribution of montmorillonite in the core can be defined, changing the direction of flow across the core would provide useful results.

Defining the degree of penetration of montmorillonite slurry into Berea is essential before lengthy experimentation takes place. Thin section analysis, or X-ray diffraction analysis of samples along the core would help define montmorillonite distribution through the pore space.

Polymerization of Stabilizer A over long periods of time was a problem identified during this research. It would be useful to define this polymerization before implementing Stabilizer A for economic ends. 


\section{CONCLUSIONS AND SUMMARY}

\subsection{Conclusions}

1. The slurry injection procedure effectively placed a quantity of montmorillonite inside Berea cores which could not be quantified.

2. Stabilizer A prevented montmorillonite from swelling or migrating within the Berea cores during fresh water injection.

3. Stabilizer A fully permeated the core, more so when injected at higher concentrations.

\subsection{Summary}

This experiment developed a method for injecting a montmorillonite/brine slurry into high permeability Berea cores. Permeability loss caused by the reaction of clays to fresh water was exacerbated by the presence of swelling clays. A novel, environmentally friendly clay stabilizer was proven effective at mitigating formation damage from swelling clays. Determination of an optimal stabilizer concentration was inconclusive. A baseline for further study was established, and direction thereof recommended. 


\section{NOMENCLATURE}

$\begin{array}{ll}\mathrm{DI} & =\text { De-ionized Water } \\ \mathrm{ICP} / \mathrm{OES} & =\text { Inductively Coupled Plasma/Optical Emission Spectrometry } \\ \mathrm{PV} & =\text { Pore Volume } \\ \mathrm{SS} & =\text { Nandstone } \\ \mathrm{NPT} & =\text { Computerized Tomography } \\ \mathrm{CT} & =\text { Degrees Centigrade } \\ { }^{\circ} \mathrm{C} & =\text { Degrees Fahrenheit } \\ { }^{\circ} \mathrm{F} & =\text { parts per million } \\ \mathrm{ppm} & =\text { meter } \\ \mathrm{m} & =\text { gram } \\ \mathrm{g} & =\text { Pascal } \\ \mathrm{Pa} & =\text { Darcy } \\ \mathrm{D} & =1 \times 10^{-6} \text { meter } \\ \mathrm{micron} & =\text { Cubic centimeter; } \mathrm{cm}^{3} \\ \mathrm{cc} & \end{array}$




\section{REFERENCES}

Churcher, P. L., French, P. R., Shaw, J. C., \& Schramm, L. L. (1991, January 1). Rock Properties of Berea Sandstone, Baker Dolomite, and Indiana Limestone. Society of Petroleum Engineers http://dx.doi.org/10.2118/21044-MS

Devine, C. S., Kalfayan, L. J., \& Ali, S. A. (2003, July 1). Method for Proper HF Treatment Selection. Petroleum Society of Canada. http://dx.doi.org/10.2118/03-07-05

El-Monier, E. A., \& Nasr-El-Din, H. A. (2010, January 1). A New Environmentally Friendly Clay Stabilizer. Society of Petroleum Engineers. http://dx.doi.org/10.2118/136061-MS

El-Monier, E. A., \& Nasr-El-Din, H. A. (2011, January 1). A Study of Several Environmentally Friendly Clay Stabilizers. Society of Petroleum Engineers. http://dx.doi.org/10.2118/142755-MS

El-Monier, E. A., \& Nasr-El-Din, H. A. (2011, January 1). A New Al-Based Stabilizer for High pH Applications. Society of Petroleum Engineers. http://dx.doi.org/10.2118/143260-MS

El-Monier, E. A., \& Nasr-El-Din, H. A. (2011, January 1). Mitigation of Fines Migration Using a New Clay Stabilizer: A Mechanistic Study. Society of Petroleum Engineers. http://dx.doi.org/10.2118/144180-MS

Gray, D.H., Rex, R.W. 1966. Formation damage in sandstone caused by clay dispersion and migration. Clay and Clay Minerals 14 (1) 355-356 http://dx.doi,org/10.1346/CCMN.1966.0140131

Himes, R. E., Vinson, E. F., \& Simon, D. E. (1991, August 1). Clay Stabilization in Low-Permeability Formations. Society of Petroleum Engineers. http://dx.doi.org/10.2118/18881-PA

Hou, X. and Jones, T. 2000. Inductively Coupled Plasma/Optical Emission Spectrometry. In Encyclopedia of Analytical Chemistry, ed. R.A. Meyers, pp. 9468-9485. Chichester: John Wiley \& Sons Ltd.

Khilar K.C., and Fogler H.S. 1984. The existence of a critical salt concentration for particle release. Journal of Colloid and Interface Science 101 (1): 214-224 ID:0021-9797/84 
Leroy, P., Revil, A., Coelho, D. 2005. Diffusion of ionic species in bentonite. Journal of Colloid and Interface Science 296 (2006): 248-255

http://dx.doi.org/10.1016/j.jcis.2005.08.034

Liu, L. 2010. Permeability and expansibility of sodium bentonite in dilute solutions. Colloids and Surfaces A: Physicochemical and Engineering Aspects 358 (2010) 68-78 http://dx.doi.org/10.1016/j.colsurfa.2010.01.033

Maley, D., Farion, G., Giurea-Bica, G., \& O'Neil, B. (2013, June 5). Non-Polymeric Permanent Clay Stabilizer for Shale Completions. Society of Petroleum Engineers. http://dx.doi.org/10.2118/165168-MS

Mohan, K.K., Vaidya, R.N., Reed, M.G., at al. 1993. Water sensitivity of sandstones containing swelling and non-swelling clays. Colloids and Surfaces A:

Physicochemical and Engineering Aspects 73 (1993) 237-254

Musharova, D., Mohamed, I. M., \& Nasr-El-Din, H. A. (2012, January 1). Detrimental Effect of Temperature on Fines Migration in Sandstone Formations. Society of Petroleum Engineers. http://dx.doi.org/10.2118/150953-MS

Peters, F. W., \& Stout, C. M. (1977, February 1). Clay Stabilization During Fracturing Treatments With Hydrolyzable Zirconium Salts. Society of Petroleum Engineers. http://dx.doi.org/10.2118/5687-PA

Pusch, R. and Kernland, O. 1994. Physio/chemical stability of smectite clays. Engineering Geology 41 (1996) 73-85. SSDI 0013-7952(95)00027-5

Reed, M. G. (1972, July 1). Stabilization of Formation Clays with Hydroxy-Aluminum Solutions. Society of Petroleum Engineers. http://dx.doi.org/10.2118/3694-PA

Sharma, M. M., Yortsos, Y. C., \& Handy, L. L. (1985, January 1). Release and Deposition of Clays in Sandstones. Society of Petroleum Engineers. http://dx.doi.org/10.2118/13562-MS

Trauger, R.J. 1994. The Strusture, Properties, and Analysis of Bentonite in Geosynthetic Clay Liners. Proc., Geosynthetic Research Institute, $8^{\text {th }}$ GRI Conference, Philadelphia, PA, USA. 13-14 December 1994.

Weaver, J. D., Nguyen, P. D., \& Loghry, R. (2011, January 1). Stabilizing Fracture Faces in Water-Sensitive Shale Formations. Society of Petroleum Engineers. http://dx.doi.org/10.2118/149218-MS 